\title{
Lime and gypsum combination improves crop and forage yields and estimated meat production and revenue in a variable charge tropical soil
}

\author{
Carlos A. C. Crusciol - Rubia R. Marques - Antonio C. A. Carmeis Filho • \\ Rogério P. Soratto $\cdot$ Claudio H. M. Costa $\cdot$ Jayme Ferrari Neto $\cdot$ \\ Gustavo S. A. Castro • Cristiano M. Pariz • André M. Castilhos • \\ Alan J. Franzluebbers
}

Received: 22 December 2018/ Accepted: 6 August 2019

(C) Springer Nature B.V. 2019

\begin{abstract}
In tropical integrated crop-livestock under no-till (NT) systems, the surface application/reapplication of lime and/or gypsum can reduce re-acidification rate of the soil and improve plant nutrition, crop yields, and profitability. This study was conducted in the Brazilian Cerrado, which has dry winters, and aimed to evaluate the effects of surface application/ reapplication of lime and/or gypsum on soil improvement, plant nutrition and crop yield improvement, as well as the forage dry matter (DM) yield, estimated meat production, and economic results. The crop rotation used between November 2004 and August 2008 was as follows: peanut (Arachis hypogaea) and white oat (Avena sativa) cultivated alone (on the first and second spring/summer and autumn/winter, respectively) and corn (Zea mays) intercropped with palisade grass [Urochloa brizantha cv. 'Marandu']
\end{abstract}

C. A. C. Crusciol $(\bowtie) \cdot$ R. R. Marques ·

A. C. A. Carmeis Filho - R. P. Soratto - J. Ferrari Neto Department of Crop Science, College of Agricultural Sciences, São Paulo State University (UNESP), Av. Universitária, 3780, Botucatu, São Paulo 18610-034, Brazil

e-mail: carlos.crusciol@unesp.br

C. H. M. Costa

Special Academic Unit of Agricultural Sciences, Federal University of Goiás (UFG), Jatai, Goiás, Brazil

G. S. A. Castro

Brazilian Agricultural Research Corporation (EMBRAPA), Campinas, São Paulo, Brazil and pasture (on the third and fourth spring/summer and autumn/winter, respectively). The experimental design was a randomized block with four replications. The treatments consisted of natural conditions of a sandy clay loam kaolinitic and thermic Typic Haplorthox (control) and the surface application of lime and/or gypsum in October 2002 and reapplication in November 2004. Surface liming was an efficient practice for increasing $\mathrm{pH}$ and reducing the exchangeable acidity $(\mathrm{H}+\mathrm{Al})$ and concentration of $\mathrm{Al}$ extending to a depth of $0.60 \mathrm{~m}$. Gypsum application increased $\mathrm{Ca}^{2+}$ levels through the soil profile. Liming (with or without gypsum) had a positive effect on the nutrient acquisition by peanut, white oat, and corn crops, producing on average $48 \%, 52 \%$, and $61 \%$ more pod and grain yield, respectively, than that obtained in the absence of soil amendments and with gypsum

C. M. Pariz $(\bowtie) \cdot$ A. M. Castilhos

Department of Animal Nutrition and Breeding, School of Veterinary Medicine and Animal Science, São Paulo State University (UNESP), Botucatu, São Paulo, Brazil e-mail: cmpzoo@gmail.com

\section{A. J. Franzluebbers $(\bowtie)$}

United States Department of Agriculture, Agricultural

Research Service, Raleigh, NC, USA

e-mail: alan.franzluebbers@ars.usda.gov 
alone. The surface application of lime + gypsum also promoted forage DM yield of corn-palisade grass intercropping $22 \%$ higher than lime application and $164 \%$ higher than control; estimated meat production $26 \%$ higher than lime application and 225\% higher than control, and increased economic results during four growing seasons. The surface application of lime + gypsum is an essential tool for food production in NT tropical agriculture with high soil acidity.

Keywords Soil acidity - Soil amendment · Integrated crop-livestock system · Grain yield . Profitability

\section{Introduction}

The no-till (NT) system is one of the main strategies adopted to mitigate soil degradation. In this production model, the preservation of agricultural ecosystems is the main objective; in addition, this strategy has the potential to promote the recovery of areas that currently are considered unproductive. Because of its adaptability and enormous benefits for soil biodiversity, NT system has been adopted in various regions of the world, especially in countries such as Argentina, Australia, Brazil, Canada, and the United States (Derpsch and Friedrich 2009). The large expansion of NT system is primarily related to the productivity gains observed in legume and cereal crops; however, chemical disorders due to soil acidity still limit the yield potential (Costa and Crusciol 2016; Tiritan et al. 2016).

The technique most commonly used to reduce soil acidity in NT systems is surface liming. This practice reduces the acidity on the soil surface in a short time, but its effects at deeper layers are slow, particularly in variable charge soils (Ernani et al. 2004; Soratto and Crusciol 2008a). The movement of lime through the soil varies with the type and structure of the soil, the intrinsic characteristics of the product, the climatic conditions, the acid fertilizer management and the crop system (Caires et al. 2005).

In regions with regular rainfall distributions such as regions under tropical conditions, positive responses of grain yield due only to surface liming at times cannot be verified (Caires et al. 2006, 2008, 2011) because the formation of a thicker layer with high chemical quality is necessary to exploit the yield potential of modern grain cultivars and is essential to reach high yields (Nora et al. 2017a). Therefore, in tropical regions, where dry spells often occur during the rainy season and the dry winter, subsoil acidity is an important factor limiting crop productivity (Marsh and Grove 1992; Sumner et al. 1986). This effect has been attributed to the toxic effects of $\mathrm{Al}$ on root growth at certain depths, inducing water stress and impeding nutrient uptake by plants (Caires et al. 2008). According to Sumner (1990), the ameliorative effects of gypsum on subsoil acidity stem from one or more of the following mechanisms: increased levels of subsoil $\mathrm{Ca}$; formation of complexes among $\mathrm{Al}$ and sulfate $\left(\mathrm{SO}_{4}\right)$ and fluoride $(\mathrm{F})$, which makes $\mathrm{Al}$ nontoxic; ligand exchange of $\mathrm{SO}_{4}$ for hydroxyls $(\mathrm{OH})$ on sesquioxide surfaces resulting in the so-called "selfliming" effect; precipitation of basic aluminum sulfate minerals, which renders the labile $\mathrm{Al}$ insoluble; and salt sorption in which $\mathrm{SO}_{4}$ is specifically adsorbed, which causes the removal of some Al from solution. Thus, lime + gypsum surface application is an important strategy to circumvent these limits due to the higher solubility of gypsum, being an effective strategy to increase the vertical movement of exchangeable bases in the rooting zone under NT system (Nora and Amado 2013; Nora et al. 2017b). In addition, the alleviation of subsoil acidity can promote greater root development of crop species, increasing the plants' tolerance to water stress during dry spells, allowing high yields to be achieved (Caires et al. 2001; Bossolani et al. 2018).

The amount of soil organic matter (SOM) is considered an important factor for reduction of free Al levels; however, tropical soils, such as Oxisols and Ultisols, exhibit a naturally low SOM content (Silva and Mendonça 2007). In NT system, the addition of organic residues yields organic compounds that form complexes with $\mathrm{Ca}$, allowing its percolation in the soil profile, in addition to reducing the toxic effect of $\mathrm{Al}$ in acid surface soils, but cash crops produce low amounts of straw (Alford et al. 2003; Allen et al. 2007).

One of the strategies to increase the quantity and quality of the straw for the continuity of NT system is the introduction of tropical perennial grasses, such as palisade grass Urochloa brizantha (Hochst. Ex A. Rich.) R.D. Webster (syn. Brachiaria brizantha), intercropped with grain crops such as corn [Zea mays L.] (Crusciol et al. 2015; Pariz et al. 2016, 2017a, b), 
sorghum [Sorghum bicolor (L.) Moench] (Costa et al. 2016; Mateus et al. 2016) and soybeans [Glycine max (L.) Merr.] (Crusciol et al. 2012, 2014). This approach could be a key strategy to enhance the early establishment and successful production of a dry winterseason (low and irregular rainfall) forage (grazed by animals or cut and removed as fodder) in integrated crop-livestock (ICL) systems. In ICL systems, after animals graze the leaves, the plant residues (mainly stems) in pastures remain to be desiccated. Thus, the adoption of integrated systems may be one of the best alternatives for farmers to increase income and simultaneously achieve sustainability in tropical regions such as the Brazilian Cerrado and African Savanna. ICL systems are considered the "new green revolution in the tropics" (Pariz et al. 2016) due to their productive economic and environmental benefits, and these systems can contribute to increased future global food production (Franzluebbers and Stuedemann 2014; Wirsenius et al. 2010). In addition, the improvement of mixed-crop and livestock production is crucial for improvement of social and economic conditions for small-scale producers and mitigation of human suffering (Herrero et al. 2010).

Most of the agricultural research related to ameliorating acidic soils in tropical and subtropical regions has focused on developing methods to identify liming requirements for soil amelioration and on determining the rates and application methods that result in higher crop responses (Martins et al. 2014a, b, 2016). Despite such efforts, few approaches have been developed to determine the processes and management practices that cause the return of the soil to acidic conditions. Little is known concerning the long-term effect of surface liming and gypsum application on ICL under NT system, its acidification processes after soil amelioration and how such processes affect nutrientuse efficiency. Intercropping grain with forage crops is a new practice and will require more information before widespread adoption (Mateus et al. 2016). For example, knowledge of changes in soil chemical attributes and their effects on grain and pasture yield is necessary to establish and adjust lime and gypsum requirements in a crop rotation scheme under NT system (Tiritan et al. 2016).

Our hypotheses were as follows: in long-term tropical ICL systems, the surface application of lime can reduce the soil re-acidification rate and improve crop yields and forage compared with those obtained under natural soil conditions, regardless of the weather conditions. The application of gypsum improves soil fertility and reduces soil subsurface acidity, which is reflected by higher yields of grains and forage. Thus, the present study was conducted over four growing seasons in a region with dry winters (Brazilian Cerrado) and aimed to evaluate the effects of the surface application/reapplication of lime and/or gypsum on soil improvement, plant nutrition and crop yield improvement, as well as the forage DM yield, estimated meat production, and economic results. The crop rotation used was as follows: peanut (Arachis hypogaea L.) and white oat (Avena sativa L.) cultivated alone and corn intercropped with palisade grass and pasture.

\section{Materials and methods}

Site description, experimental design, and treatments

This study is part of an experiment located in Botucatu, São Paulo State, Brazil $\left(48^{\circ} 23^{\prime} \mathrm{W}\right.$, $22^{\circ} 51^{\prime} \mathrm{S}$ ), and initiated in October 2002 (Soratto and Crusciol 2008a, b, c). The original experiment had a greater number of treatments, but the present study dealt only with four treatments and the period from October 2004 to August 2008. The elevation of the experimental area is $765 \mathrm{~m}$ above sea level. The soil was classified as a sandy clay loam kaolinitic and thermic Typic Haplorthox (USDA 1999) with sand, silt, and clay contents of 540, 110, and $350 \mathrm{~g} \mathrm{~kg}^{-1}$, respectively, at a depth of $0-0.20 \mathrm{~m}$. In the subsoil $(0.20-0.40 \mathrm{~m})$, the clay content was $360 \mathrm{~g} \mathrm{~kg}^{-1}$. The bulk density at depth $0-0.20 \mathrm{~m}$ was $1.128 \mathrm{t} \mathrm{m}^{-3}$. The climate is Cwa, tropical with dry winters and hot and rainy summers, according to the Köppen climate classification system. The long-term (1956-2016) mean annual maximum and minimum temperatures are 26.1 and $15.3{ }^{\circ} \mathrm{C}$, respectively, with a mean annual precipitation of $1359 \mathrm{~mm}$ (Unicamp 2016). During the experimental period, rainfall was measured daily (Fig. 1) using a 50-cm tall plastic rain gauge (pluviometer) placed on the ground at a height of $1.20 \mathrm{~m}$ in the experimental area.

The experimental design was a randomized complete block with four treatments and four replications. The treatments were as follows: natural soil conditions 
Fig. 1 Monthly rainfall (mm, bars) and temperature $\left({ }^{\circ} \mathrm{C}\right.$, line) at the experiment site at Botucatu, São Paulo State, Brazil, from

November to November in the agricultural years of a 2004-2005, b 2005-2006, c 2006-2007 and d 2007-2008

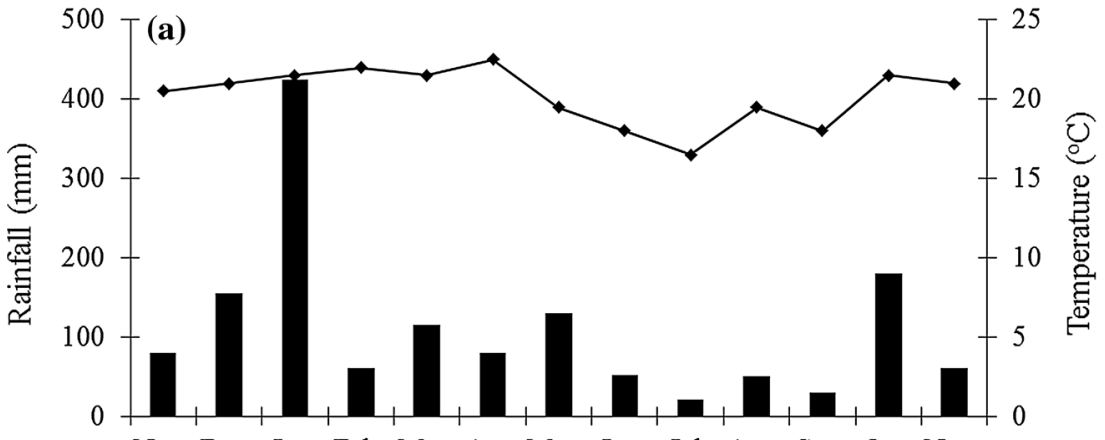

Nov- Dec- Jan- Feb- Mar- Apr- May- Jun- Jul- Aug- Sep- Oct- Nov-

$\begin{array}{lllllllllllll}04 & 04 & 05 & 05 & 05 & 05 & 05 & 05 & 05 & 05 & 05 & 05 & 05\end{array}$

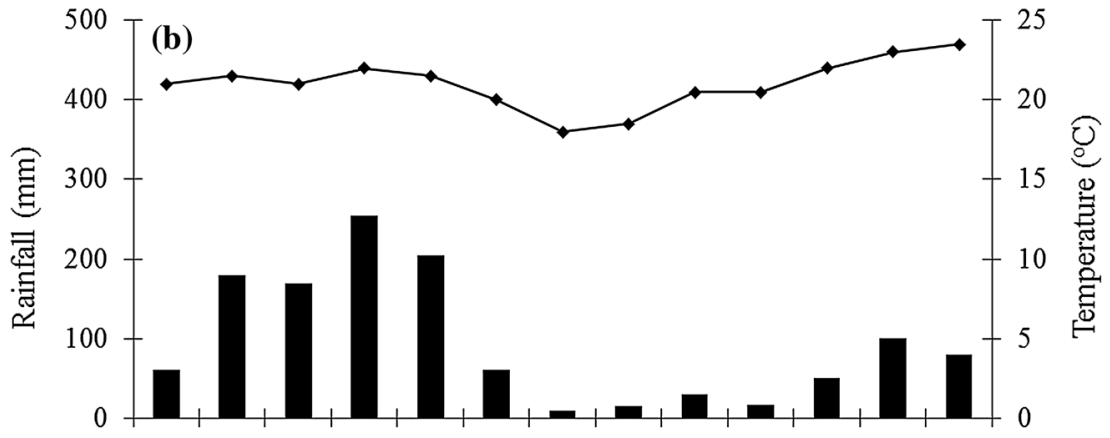

Nov- Dec- Jan- Feb- Mar- Apr- May- Jun- Jul- Aug- Sep- Oct- Nov-

$\begin{array}{lllllllllllll}05 & 05 & 06 & 06 & 06 & 06 & 06 & 06 & 06 & 06 & 06 & 06 & 06\end{array}$

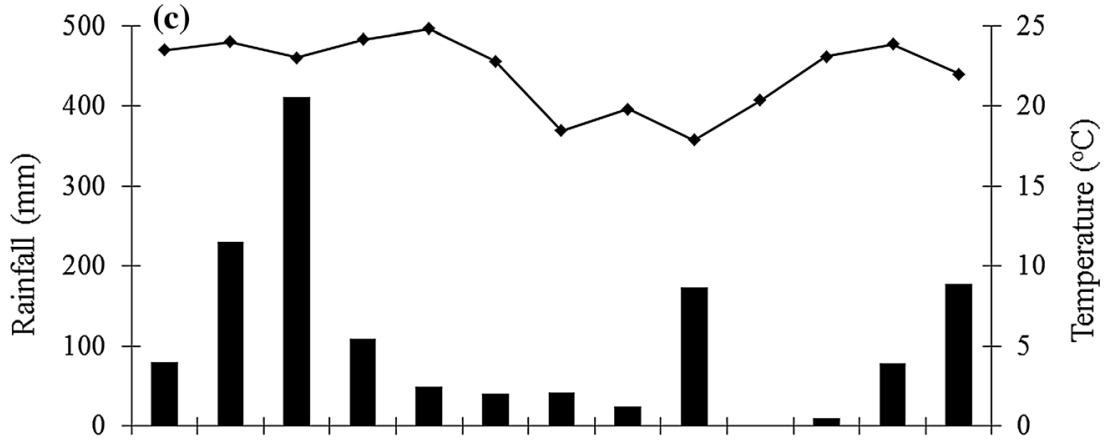

Nov- Dec- Jan- Feb- Mar- Apr- May- Jun- Jul- Aug- Sep- Oct- Nov-

$\begin{array}{lllllllllllll}06 & 06 & 07 & 07 & 07 & 07 & 07 & 07 & 07 & 07 & 07 & 07 & 07\end{array}$

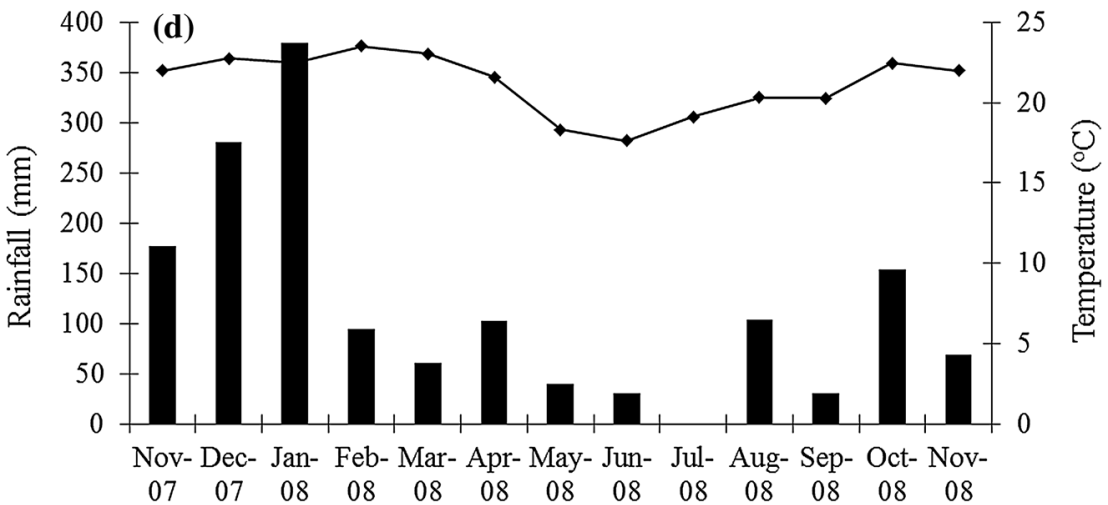


(control—without lime and gypsum), lime application, gypsum application, and combined lime plus gypsum applications. The plot size was $5.4 \mathrm{~m} \times 9.0 \mathrm{~m}$.

The dolomitic lime rate (DLR) was calculated to increase the BS in the topsoil $(0-0.20 \mathrm{~m})$ to $70 \%$, as shown in Eq. (1), according to the methodology proposed by Quaggio and van Raij (1997):

$\operatorname{DLR}\left(\mathrm{tha}^{-1}\right)=\left(\mathrm{BS}_{2}-\mathrm{BS}_{1}\right) \mathrm{CEC} /(10 \mathrm{ECCE})$

where $\mathrm{BS}_{2}$ is the estimated base saturation (70\%), and $\mathrm{BS}_{1}$ is the base saturation measured in the soil analysis, as shown in Eq. (2). ECCE is the effective calcium carbonate equivalents.

$\mathrm{BS}_{1}(\%)=\left(\mathrm{Ca}_{\mathrm{ex}}+\mathrm{Mg}_{\mathrm{ex}}+\mathrm{K}_{\mathrm{ex}}\right) 100 / \mathrm{CEC}$

where $\mathrm{Ca}_{\mathrm{ex}}, \mathrm{Mg}_{\mathrm{ex}}$, and $\mathrm{K}_{\mathrm{ex}}$ are basic exchangeable cations, and CEC is the total cation exchange capacity, calculated as indicated in Eq. (3):

$$
\begin{aligned}
\mathrm{CEC}\left(\mathrm{mmol}_{\mathrm{c}} \mathrm{kg}^{-1}\right)= & \mathrm{Ca}_{\mathrm{ex}}+\mathrm{Mg}_{\mathrm{ex}}+\mathrm{K}_{\mathrm{ex}} \\
& + \text { total acidity in } \mathrm{pH} 7.0(\mathrm{H}+\mathrm{Al})
\end{aligned}
$$

The gypsum rate (GR) was calculated using Eq. (4), according to the methodology proposed by Quaggio and van Raij (1997).

$$
\operatorname{GR}\left(\mathrm{tha}^{-1}\right)=6 \mathrm{CL} / 1000
$$

where $\mathrm{CL}$ is the clay content $\left(\mathrm{g} \mathrm{kg}^{-1}\right)$ in the soil layer of $0.20-0.40 \mathrm{~m}$.

At the beginning of the experiment (October 2002), lime was surface-applied at a rate of $2.7 \mathrm{tha}^{-1}$ (Soratto and Crusciol 2008a). Gypsum was applied 1 day after liming at a rate of $2.1 \mathrm{t} \mathrm{ha}^{-1}$. The reapplication was based on a soil analysis carried out in August 2004, in which the BS (0-0.20 m soil layer) in the treatments with lime alone (standard treatment) reached value lower than $50 \%$ (Table 1), the preestablished critical level for the amendments reapplication. Thus, in November 2004, the reapplication of lime and gypsum was performed at rates of 2.0 and $2.1 \mathrm{t} \mathrm{ha}^{-1}$, respectively. The products were applied without incorporation into the soil on black oat straw and 3 days before peanuts were sown. The control plots did not receive any application in 2002 or 2004.

The dolomitic limestone was composed of $17 \% \mathrm{Ca}$, $11 \% \mathrm{Mg}$, and $71 \%$ ECCE. Among the lime particles, $68.8,92.4$, and $99.7 \%$ passed through 50-, 20-, and 10 -mesh sieves, respectively. Gypsum $\left(\mathrm{CaSO}_{4} \cdot 2 \mathrm{H}_{2} \mathrm{O}\right)$, a by-product obtained from the Brazilian phosphoric acid industry, was composed of $22 \% \mathrm{Ca}, 17 \% \mathrm{~S}$, and a small residue of $0.1 \% \mathrm{P}$ and $\mathrm{F}$, also known as phophogypsum. Among the gypsum particles, 60.0

Table 1 Chemical characteristics of the soil in October 2002 prior to the beginning of the experiment and in August 2004 before the surface lime and/or gypsum reapplication in the treatment with lime alone (standard treatment)

\begin{tabular}{llllllllllll}
\hline $\begin{array}{l}\text { Depth } \\
(\mathrm{m})\end{array}$ & $\begin{array}{l}\mathrm{pH} \\
\left(\mathrm{CaCl}_{2}\right)\end{array}$ & $\begin{array}{l}\mathrm{SOM} \\
\left(\mathrm{g} \mathrm{kg}^{-1}\right)\end{array}$ & $\begin{array}{l}\mathrm{P}(\mathrm{resin}) \\
\left(\mathrm{mg} \mathrm{kg}^{-1}\right)\end{array}$ & $\begin{array}{l}\mathrm{l}+\mathrm{Al} \\
\left(\mathrm{mmol}_{\mathrm{c}} \mathrm{kg}^{-1}\right)\end{array}$ & $\mathrm{Kl}$ & $\mathrm{Ca}$ & $\mathrm{Mg}$ & $\mathrm{CEC}$ & $\mathrm{AEC}$ & $\mathrm{BS}(\%)$ \\
\hline October 2002 & & & & & & & & & & & \\
$0-0.05$ & 5.0 & 27 & 17 & 38 & 4.0 & 1.6 & 28 & 12 & 80 & 2.1 & 53 \\
$0.05-0.10$ & 4.9 & 25 & 12 & 40 & 3.7 & 1.0 & 31 & 14 & 86 & 2.4 & 53 \\
$0.10-0.20$ & 4.3 & 24 & 7 & 56 & 9.1 & 0.4 & 21 & 8 & 85 & 3.3 & 34 \\
$0.20-0.40$ & 3.9 & 22 & 6 & 83 & 17.9 & 0.2 & 18 & 5 & 106 & 4.0 & 22 \\
$0.40-0.60$ & 3.9 & 23 & 4 & 100 & 24.8 & 0.2 & 19 & 4 & 123 & 4.1 & 19 \\
$0-0.20$ & 4.6 & 25 & 11 & 48 & 6.5 & 0.9 & 25 & 11 & 85 & 2.8 & 44 \\
August 2004 & & & & & & & & & & & \\
$0-0.05$ & 5.2 & 27 & 61 & 32 & 1.6 & 1.3 & 31 & 16 & 80 & 2.2 & 60 \\
$0.05-0.10$ & 4.9 & 26 & 32 & 35 & 2.3 & 1.3 & 23 & 12 & 71 & 2.1 & 45 \\
$0.10-0.20$ & 4.6 & 25 & 28 & 44 & 4.8 & 1.1 & 15 & 8 & 68 & 2.3 & 35 \\
$0.20-0.40$ & 4.2 & 23 & 14 & 58 & 12.9 & 0.7 & 10 & 5 & 74 & 2.0 & 22 \\
$0.40-0.60$ & 4.0 & 23 & 15 & 78 & 17.6 & 0.6 & 8 & 3 & 90 & 3.1 & 13 \\
$0-0.20$ & 4.8 & 26 & 37 & 39 & 3.4 & 1.2 & 21 & 11 & 72 & 2.2 & 46 \\
\hline
\end{tabular}

$S O M$ soil organic matter, $C E C$ cation exchange capacity, $A E C$ anion exchange capacity, $B S$ base saturation 
and $90.0 \%$ passed through 50 - and 20-mesh sieves, respectively.

Soil sampling and analysis

In October 2002 (prior to the beginning of the experiment), eight soil subsamples were randomly obtained from useable areas of each plot at depths of $0-0.05, \quad 0.05-0.10, \quad 0.10-0.20, \quad 0.20-0.40, \quad$ and $0.40-0.60 \mathrm{~m}$ and were combined into one composite sample to determine the soil chemical attributes (Table 1). In October 2002 lime and gypsum treatments were surface-applied (Soratto and Crusciol 2008a). In the growing season of 2002/2003, upland rice (Oryza sativa L.) was planted in the summer and black oat (Avena strigosa Schreb.) in the autumn, and in the growing season of 2003/2004, common bean (Phaseolus vulgaris L.) was planted in the summer and black oat in the autumn. In August 2004 (before the reapplication of lime and/or gypsum in November 2004), the same procedure of soil sampling was carried out in the treatment with lime alone (standard treatment), taken into account for reapplications (Table 1).

Soil chemical attributes in each plot were also evaluated at these depths in two sampling periods: 12 (November 2005) and 24 (November 2006) months after the reapplication of lime and/or gypsum (i.e., 36 and 48 months after the beginning of the experiment, respectively). Eight subsamples were collected at random from each plot and between rows of the previous crop to form a composite sample. The samples were dried and sieved with 10-mesh sieves. The soil $\mathrm{pH}$ was determined in a $0.01 \mathrm{~mol} \mathrm{~L}^{-1} \mathrm{CaCl}_{2}$ suspension (1:2.5 soil/solution). The SOM was determined by the Walkley-Black method (Walkley and Black 1934). The total acidity at $\mathrm{pH} 7.0(\mathrm{H}+\mathrm{Al})$ was estimated by the SMP-buffer solution method (van Raij et al. 2001). The exchangeable $\mathrm{Al}$ was extracted with neutral $1 \mathrm{~mol} \mathrm{~L}^{-1} \mathrm{KCl}$ at a 1:10 soil/solution ratio and determined by titration with a $0.025 \mathrm{~mol} \mathrm{~L}^{-1}$ $\mathrm{NaOH}$ solution. Phosphorus and exchangeable $\mathrm{Ca}$, $\mathrm{Mg}$, and $\mathrm{K}$ were extracted with ion-exchange resins; in the extract, $\mathrm{P}$ was determined colorimetrically, and cations by atomic absorption spectrometry (van Raij et al. 2001). Using the exchangeable bases and total acidity at $\mathrm{pH} 7.0(\mathrm{H}+\mathrm{Al})$ results, the base saturation (BS) values were calculated (van Raij et al. 2001). Soil $\mathrm{S}^{-} \mathrm{SO}_{4}{ }^{2-}$ extraction were performed by calcium phosphate extraction at $0.01 \mathrm{~mol} \mathrm{~L}^{-1}$ in a $1: 2.5$ soil/solution ratio and later determined by the turbidimetric method using $\mathrm{BaSO}_{4}$ (Vitti 1988). The anion exchange capacity (AEC) was determined following the method outlined by Gillman (1979); briefly, this method consists of equilibrating the soil at its natural $\mathrm{pH}$ with $0.002 \mathrm{M} \mathrm{BaCl}_{2}$, extracting the $\mathrm{Cl}^{-}$ions with $0.005 \mathrm{M} \mathrm{MgSO}_{4}$ and determining the amount of desorbed $\mathrm{Cl}^{-}$, which corresponds to AEC. The analysis of AEC is important because the direct relationship observed between sulfate adsorption and AEC (Alves and Lavorenti 2004) suggests the occurrence of electrostatic adsorption of sulfate on $-\mathrm{OH}_{2}{ }^{+}$ surface groups as proposed by Marsh et al. (1987).

\section{Crop management}

The crop rotation used between November 2004 and August 2008 was as follows: peanut and white oat cultivated alone (first and second spring/summer and autumn/winter, respectively) and corn intercropped with palisade grass and pasture (third and fourth spring/summer and autumn/winter, respectively). On October 16, 2004, black oat had been desiccated by applying glyphosate (Roundup Original, $1800 \mathrm{~g}$ acid equivalents $\mathrm{ha}^{-1}$, Monsanto Brazil). A boom sprayer with a spray volume of $200 \mathrm{~L} \mathrm{ha}^{-1}$ was used. This desiccation (same product and dose) was also performed before sowing peanut, white oat and corn in subsequent growing seasons. All crops were sown using no-till seeding (Semeato, model Personale Drill 13, Passo Fundo, RS, Brazil). The cultural practices used for peanut and white oat cultivated alone and corn intercropped with palisade grass are described in Table 2.

Determination of plant nutrition, yield components, and crop yield

\section{Peanut}

When the peanut plants were at the full-bloom stage, ten peanut plants per plot were sampled to evaluate the shoot DM (non-grain biomass) at ground level, and the apical leaf clusters of the main branches of 40 plants were sampled per plot, according to Ambrosano et al. (1997). The material was dried in an oven at $65^{\circ} \mathrm{C}$ to constant weight and then ground for macronutrient analyses. The concentrations of $\mathrm{N}, \mathrm{P}, \mathrm{K}, \mathrm{Ca}, \mathrm{Mg}$, and $\mathrm{S}$ were determined using methods described by Malavolta et al. (1997). 


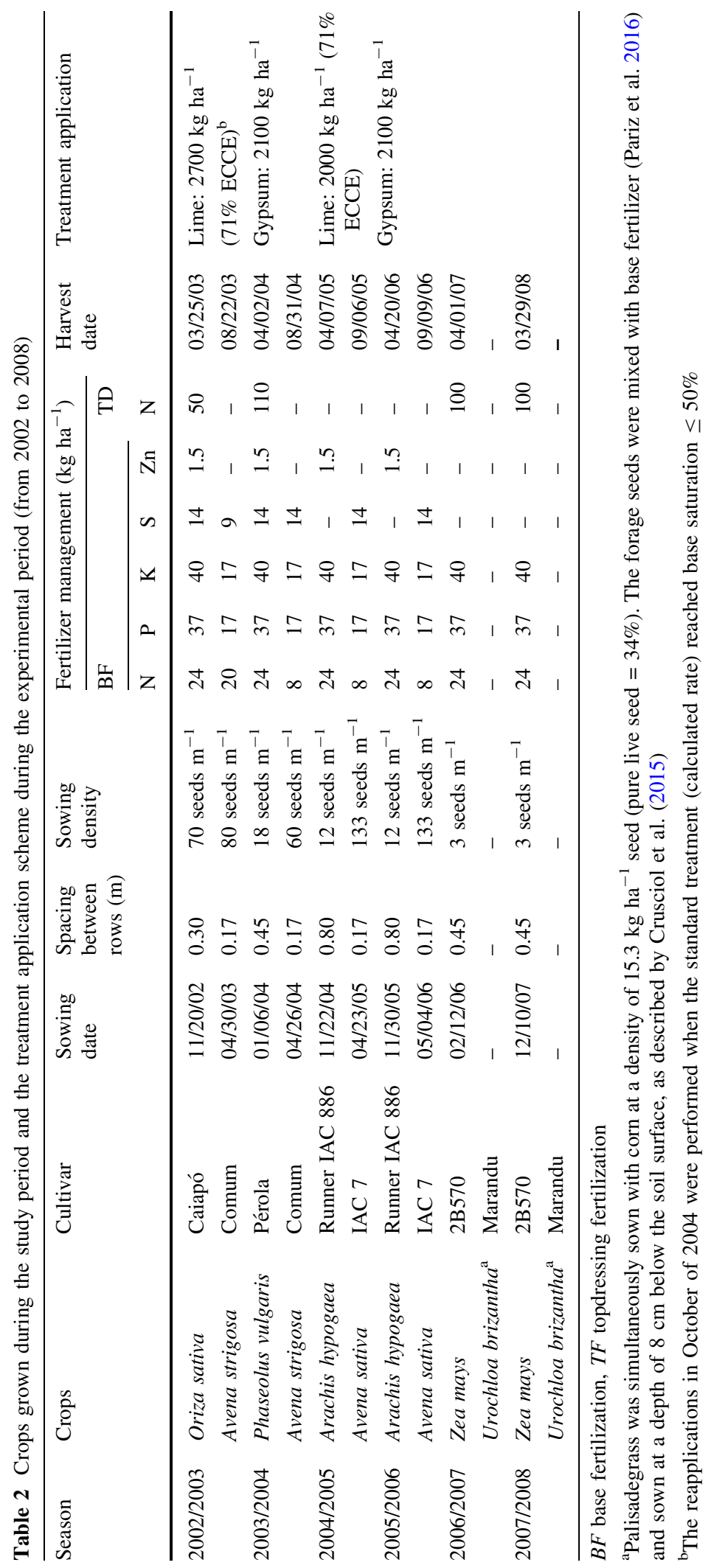


Yield components, i.e., the final population of plants (counting the number of plants in the two central rows in $8-\mathrm{m}$ rows in each plot, followed by extrapolation to the ha), the number of filled pods per plant (obtained by counting the number of pods in 10 plants that were randomly collected in the useable area), the number of kernels per pod (obtained using the following function: total number of kernels in 10 plants/total number of pods in 10 plants), the 100-kernel weight (evaluated through the random collection and weighing of four samples of 100 kernels from each plot) and the hulled-kernel yield (determined based on the kernel weight/pod weight ratio) were determined at harvest (moisture content of $90 \mathrm{~g} \mathrm{~kg}^{-1}$ ). The pod yield was determined by manually harvesting the plants in two central rows that were $6 \mathrm{~m}$ long.

\section{White oat}

In the full flowering stage, ten white oat plants per plot were sampled for the evaluation of shoot DM (nongrain biomass) at ground level, and 50 flag leaves of plants per plot were sampled (Cantarella et al. 1997)

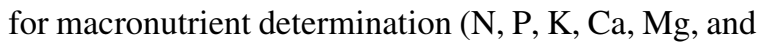
S) (Malavolta et al. 1997). The yield components, i.e., the number of panicles per square meter (obtained by counting the number of panicles in 2-m rows of plants in two central rows in the usable area of each plot), number of spikelets per panicle (obtained by counting the number of spikelets in 20 panicles in the useable area), spikelet fertility (obtained using the following function: number of grain-bearing spikelets/total number of spikelets per panicle), and 1000-grain weight (evaluated through the random collection and weighing of four samples of 1000 grains from each plot) and grain yield (moisture content of $130 \mathrm{~g} \mathrm{~kg}^{-1}$ ), were determined at harvest.

\section{Corn intercropped with palisade grass}

At the male full-flowering stage, ten corn plants per plot were sampled at ground level for the evaluation of shoot DM (non-grain biomass) at ground level, and 30 leaves (only the central third parts) were sampled at the ear base (Cantarella et al. 1997) for macronutrient determination (N, P, K, Ca, Mg, and S) (Malavolta et al. 1997). The yield components, i.e., final plant population (counting the number of plants in the two central rows in 6-m rows in each plot, followed by extrapolation to the ha), number of ears per plant (obtained using the following function: number of ears in 6-m rows/total number of plants in 6-m rows), number of kernels per ear (obtained by counting the number of grains in 10 ears picked in the useable area), and 100-grain weight (evaluated through the random collection and weighing of eight samples of 100 grains from each plot) and grain yield (moisture content of $130 \mathrm{~g} \mathrm{~kg}^{-1}$ ), were evaluated at harvest.

The forage DM yield of palisade grass were evaluated 70 (first cut) and 130 days (second cut) after the corn harvests (i.e., in June and August, respectively). All forage was cut in three spots $\left(2 \mathrm{~m}^{2}\right.$ in each area) of the plots using a manual mechanical rotary mower working $0.25 \mathrm{~m}$ high from the soil surface. After cutting, all fodder was removed from the plots. This cutting height was used to provide faster forage regrowth. The collected fodder was dried using an oven with forced-air circulation at $65^{\circ} \mathrm{C}$ for $72 \mathrm{~h}$. The DM was weighed, and the data were extrapolated to $\mathrm{tha}^{-1}$.

For crude protein evaluation, a sub-sample of palisade grass DM was used to determine the $\mathrm{N}$ concentration. $\mathrm{N}$ was extracted using $\mathrm{H}_{2} \mathrm{SO}_{4}$, and the concentration was determined using the Micro-Kjeldahl distillation method (Ma and Zuazaga 1942). The crude protein $(\mathrm{CP})$ was calculated using Eq. (5), according to the methodology proposed by AOAC (1990).

$\mathrm{CP}(\%)=\% \mathrm{~N} \times 6.25$

\section{Estimated animal stocking rate and estimated meat production}

Although grazing by animals was not performed for the palisade grass after the grain corn harvest in the winter/ spring, meat production was estimated using the Large Ruminant Nutrition System model (LRNS; http:// nutritionmodels.tamu.edu/lrns.html). The LRNS model is based on the Cornell Net Carbohydrate and Protein System (CNCPS) version 5, as described by Fox et al. (2004). The following factors were used to predict the energy and protein requirements, performance and DM intake by individual cattle fed in a group: Nellore breed, bull sex, $450 \mathrm{~kg}$ body weight, 52\% carcass yield, 22\% Body Fat Grading System and continuous grazing. For each treatment, the nutritional palisade grass composition values were used to predict the performance values. 
The DM intake by individual cattle fed in a group was $10.0 \mathrm{~kg}$ of $\mathrm{DM}$ day $^{-1}$. Due to the high crude protein content of the forage (8.4-12.0\%), the average daily weight gain (ADWG) was based on the allowable metabolizable energy and protein gain. Therefore, the ADWG was used to estimate the meat production. The DM herbage allowance was double the amount of DM intake by individual cattle, considering a grazing efficiency of $60 \%$, according to Braga et al. (2007).

The time of animal grazing was calculated using a method similar to that used by Crusciol et al. (2016a). A period of 365 days was considered, including an average corn life cycle of 115 days, a 70-days waiting period (an important waiting period after corn was harvested and before animals were grazed in palisade grass pastures), with a period of 60 days after animal grazing on palisade grass pasture for regrowth and desiccation to produce straw for the NT. Therefore, 120 days (365-115-70-60 days) were available for animal grazing for all treatments (60 days in each cut). The animal stocking rate was then estimated from the forage DM yield data, time of animal grazing (days per cut), DM intake by the individual cattle fed in a group and grazing efficiency. The animal stocking rate was multiplied by ADWG, time of animal grazing and carcass yield $(52 \%)$ to estimate the total cattle meat produced per ha.

\section{Economic evaluation}

An economic evaluation was also conducted for each treatment. The cost per ha to produce each crop was calculated similarly for each treatment (CONAB 2017). The only differences were the lime and gypsum used before the peanut crop (November 2004) and in the pasture costs we considered the animal variable costs as a function of animal stocking rate because of the different forage DM yield between treatments. The average peanut, white oat and corn grain yields ( $\left.\mathrm{tha}^{-1}\right)$ and estimated meat production $\left(\mathrm{kg} \mathrm{ha}^{-1}\right)$ were calculated, and the results were multiplied by the price per kilogram.

The net profit realization per ha was calculated using the following formula: (gross revenue-cost). The total and mean net profits were the sum over all growing seasons and the mean by growing season, respectively. We used the Brazilian national average prices from the past 5 years and converted those values to dollars (US\$) (Agrolink 2018).
Statistical analyses

All data were initially tested for normality using the Shapiro-Wilk test from the UNIVARIATE procedure of SAS (version 9.3; SAS Inst. Inc., Cary, NC, USA), and the results indicated that all data were distributed normally ( $W \geq 0.90$ ). The assumption of the homogeneity of variances was tested using Levene's test for residual errors. When variances could not be considered homogeneous $(P \leq 0.10)$, Welch's F-test was performed to determine the overall significance for the statistic of interest. The data were then analyzed using the MIXED procedure of SAS and the Satterthwaite approximation to determine the degrees of freedom for the tests of fixed effects. Treatments were considered fixed effects, and blocks were considered random effects. For crop analyses, a repeated statement was used with growing season for the same crop specified as the repeated variable and block $\times$ treatment specified as the subject. The covariance structure used in these analyses was Compound Symmetry (CS), which provided the best fit according to the Akaike information criterion. For soil analyses, a repeated statement was used with sampling period [12 (November 2005) and 24 (November 2006) months after the surface reapplication of lime and/or gypsum, which was performed in November 2004] specified as the repeated variable and block $\times$ treatment specified as the subject. The covariance structure used in these analyses was Huynh-Feldt (HF), which provided the best fit according to the Akaike information criterion. Soil depths were not included in the statistical model and were analyzed individually. The results are reported as the least square means and separated using the probability of differences option (PDIFF). The means were compared via Fisher's protected LSD test. The main factor and interaction effects were considered statistically significant at $P \leq 0.05$.

\section{Results}

Soil chemical attributes

There was no significant treatment $\times$ sampling period interaction for any soil attribute at any soil depth, so only the isolated effects of treatment and sampling period were presented (Figs. 2, 3, 4). 

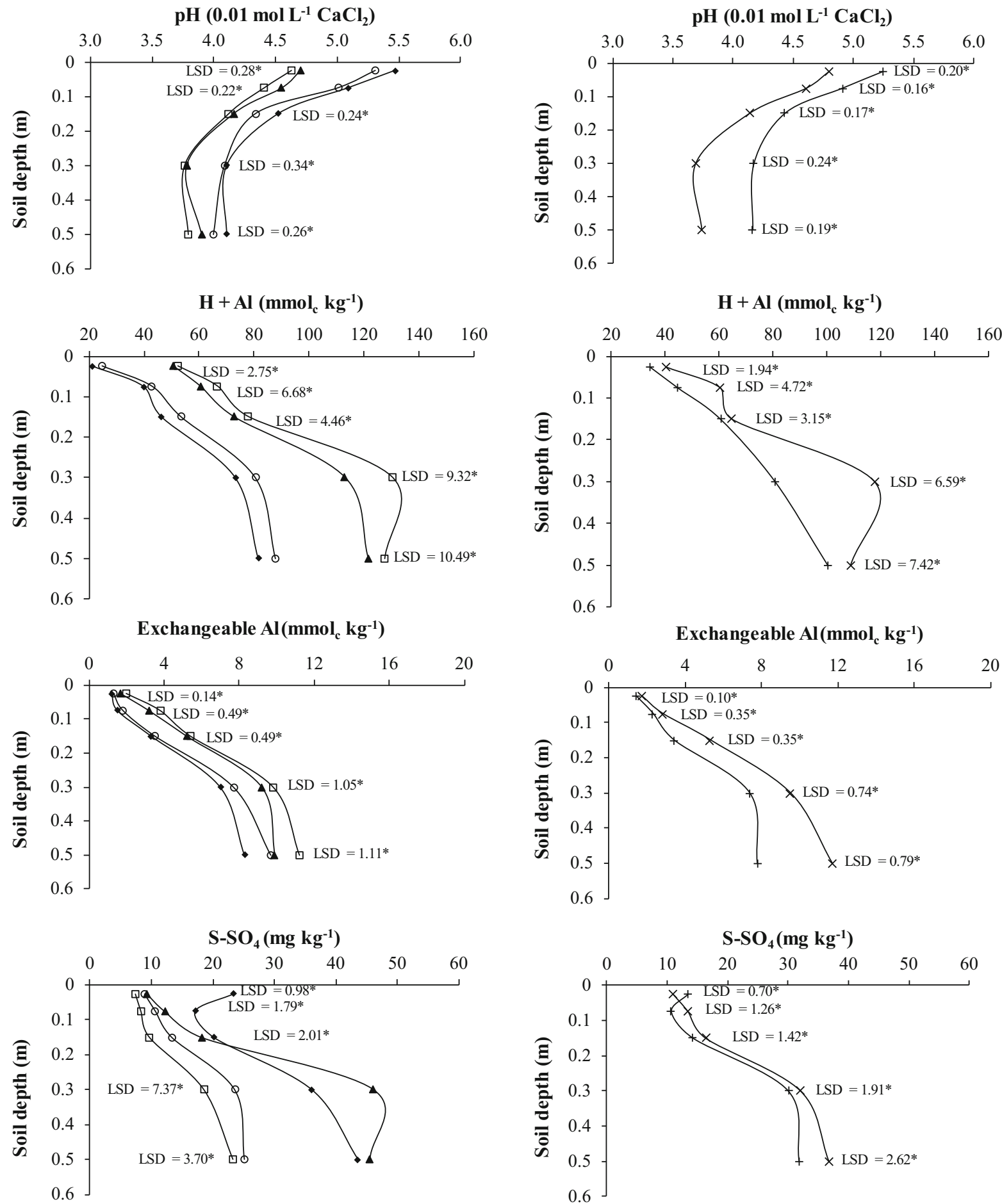

Fig. 2 Changes in $\mathrm{pH}$, total acidity $(\mathrm{H}+\mathrm{Al})$, exchangeable $\mathrm{Al}$ $\left(\mathrm{Al}^{3+}\right)$, and sulfate $\left(\mathrm{S}_{-} \mathrm{SO}_{4}\right)$ in the soil profile as affected by surface-applied lime and/or gypsum treatments. Graphics on the left show the averages over 2 year per treatment [no lime $(\square)$, gypsum $(\boldsymbol{\Delta})$, lime $(\bigcirc)$, and lime $+\operatorname{gypsum}(\diamond)$ ] and graphics

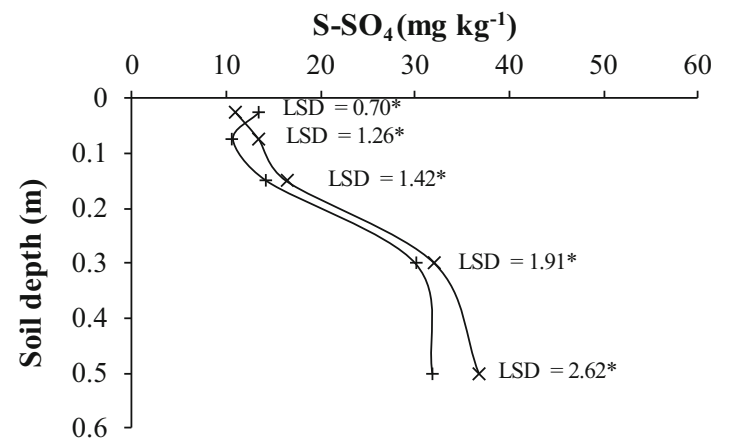

on the right show the averages of the two sampling periods [12 $(\times)$ and $24(+)$ months after treatment reapplication]. * and ns are statistically significant and not statistically significant according to the LSD (least significant difference) test $(p \leq 0.05)$, respectively 

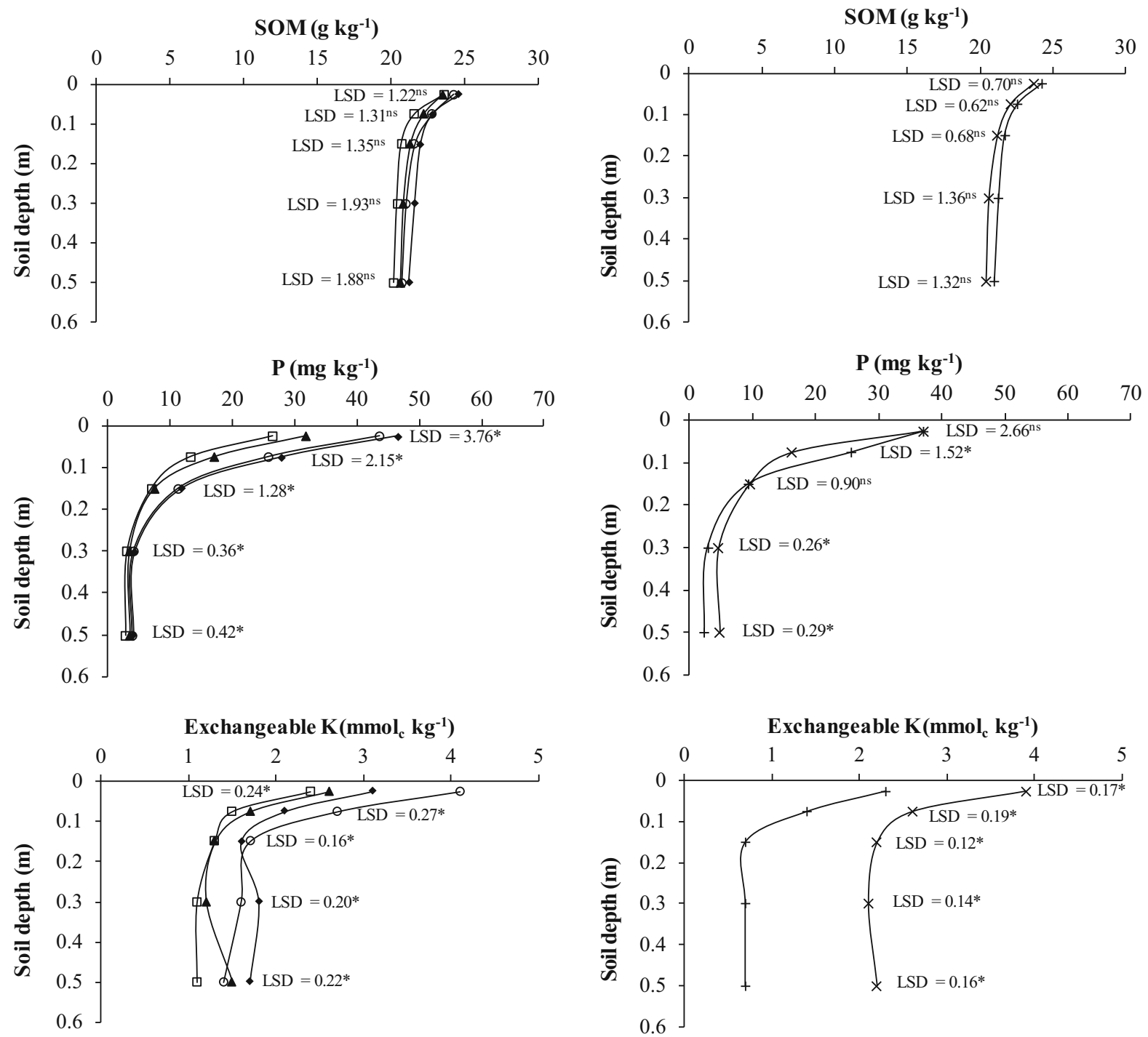

Fig. 3 Changes in soil organic matter (SOM), phosphorus (P), and potassium $(\mathrm{K})$ in the soil profile as affected by surfaceapplied lime and/or gypsum treatments. Graphics on the left show the averages over 2 year per treatment [no lime ( $\square$ ), gypsum $(\mathbf{\Lambda})$, lime $(\bigcirc)$, and lime $+\operatorname{gypsum}(\bullet)]$ and graphics

Surface liming increased the soil $\mathrm{pH}$ in the uppermost soil surface layers $(0-0.20 \mathrm{~m})$; additionally, the acidity neutralization reaction was slightly improved by gypsum association, also inducing a higher increase in the soil $\mathrm{pH}$ in all layers compared to control (Fig. 2). In most soil layers, significant benefits of lime and the combination of lime and gypsum on the potential acidity level $(\mathrm{H}+\mathrm{Al})$ and exchangeable $\mathrm{Al}$ were verified, persisting up to

on the right show the averages of the two sampling periods [12 $(\times)$ and $24(+)$ months after treatment reapplication]. ${ }^{*}$ and $\mathrm{ns}$ are statistically significant and not statistically significant according to the LSD (least significant difference) test $(p \leq 0.05)$, respectively

$0.60 \mathrm{~m}$. Compared to liming alone, the application of lime + gypsum reduced the $\mathrm{H}+\mathrm{Al}$ level in the $0-0.05$ and $0.10-0.20 \mathrm{~m}$ soil layers. In addition, the gypsum application reduced the $\mathrm{H}+\mathrm{Al}$ level in the $0.10-0.20$ and $0.20-0.40 \mathrm{~m}$ compared to control. The exchangeable Al was reduced by gypsum application in the soil layers $0-0.05,0.10-0.20$, and $0.40-0.60 \mathrm{~m}$ in relation to control, and lime and lime + gypsum reduced compared to gypsum and 

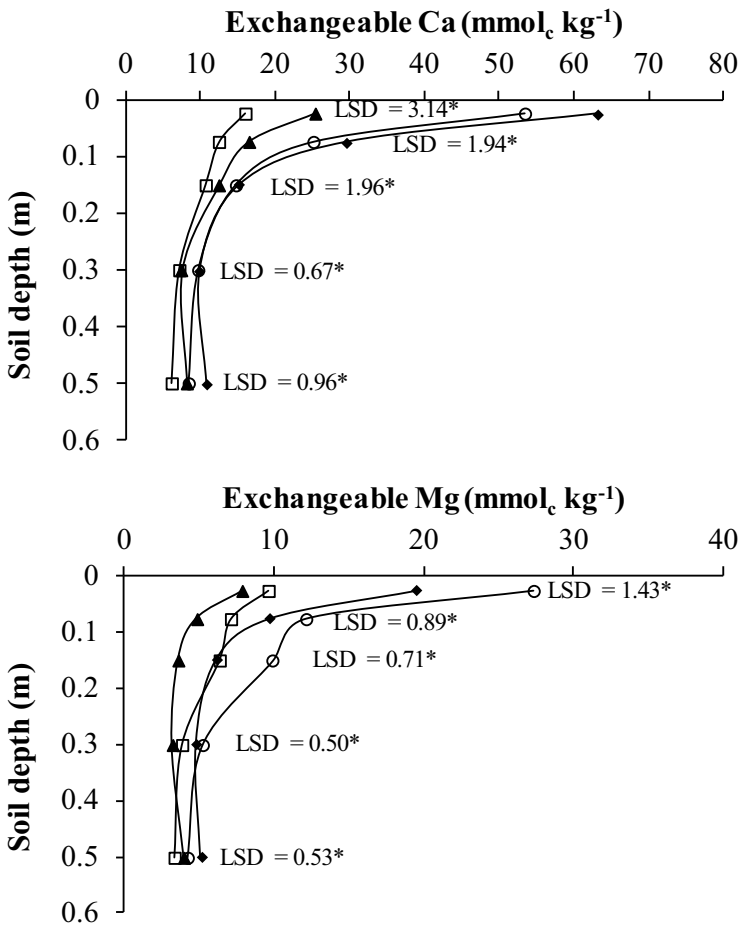

Base saturation (\%)

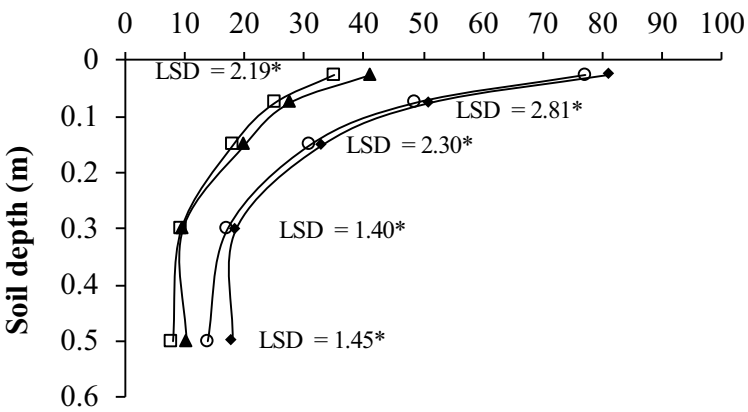

Fig. 4 Changes in exchangeable calcium $(\mathrm{Ca})$, magnesium $(\mathrm{Mg})$, and base saturation in the soil profile as affected by surface-applied lime and/or gypsum treatments. Graphics on the left show the averages over 2 year per treatment [no lime ( $\square$ ), gypsum $(\boldsymbol{\Delta})$, lime $(\bigcirc)$, and lime $+\operatorname{gypsum}(\diamond)$ ] and graphics

control up to $0.40 \mathrm{~m}$, therefore the lime + gypsum reduced $\mathrm{Al}^{3+}$ level in the $0.40-0.60 \mathrm{~m}$ soil layer compared to lime. At 24 months after treatment reapplication, the soil acidity in all soil profiles was reduced compared to that after 12 months (i.e., $\mathrm{pH}$ increased and potential acidity level and exchangeable $\mathrm{Al}$ decreased).

The application of gypsum alone promoted the greatest $\mathrm{S}_{-} \mathrm{SO}_{4}$ availability especially in the soil layers
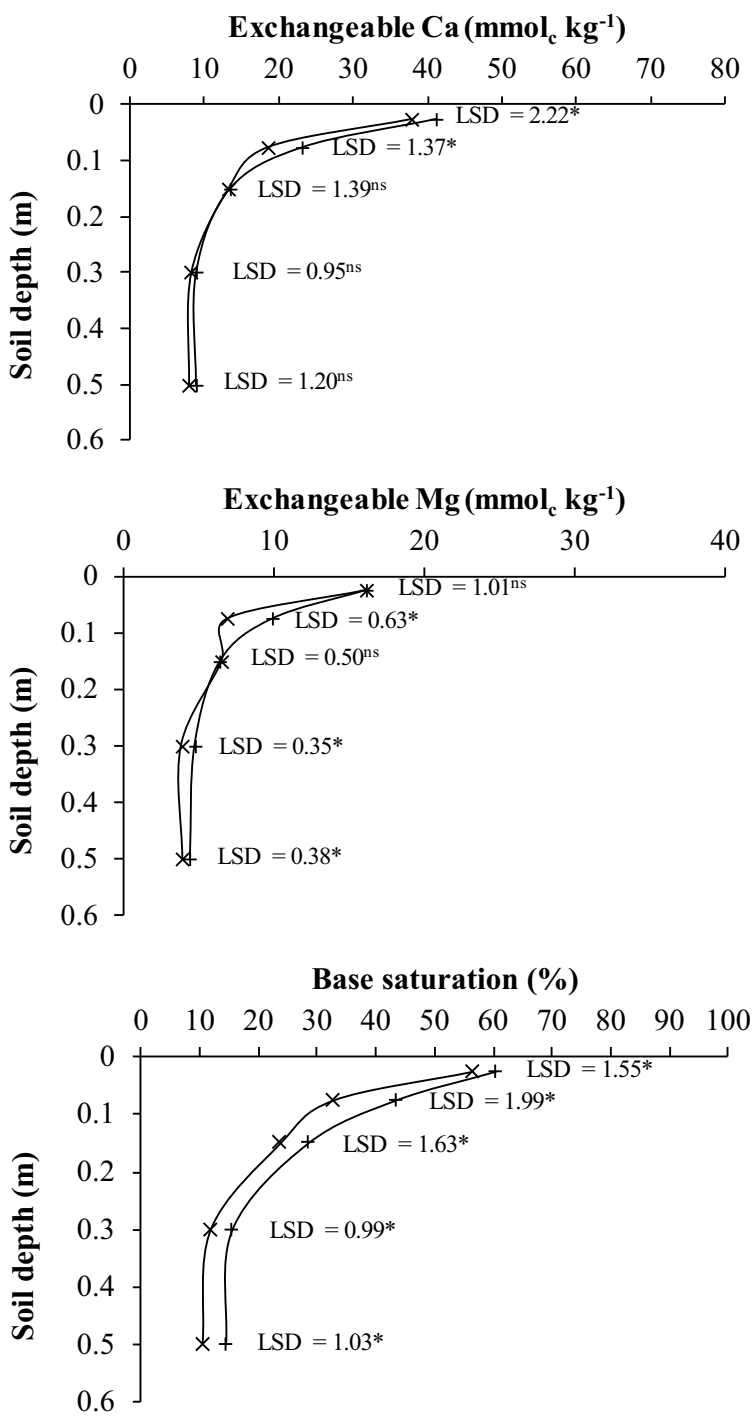

on the right show the averages of the two sampling periods [12 $(\times)$ and $24(+)$ months after treatment reapplication]. * and ns are statistically significant and not statistically significant according to the LSD (least significant difference) test $(p \leq 0.05)$, respectively

below 0.05-m depths compared to the control (Fig. 2). In the $0-0.20-\mathrm{m}$ soil layers, the effects were more pronounced with the lime + gypsum application. In the deepest layers of the soil, the application of gypsum alone or lime + gypsum provided a significant increase in the concentration of $\mathrm{S}_{-} \mathrm{SO}_{4}$. The soil $\mathrm{S}_{-} \mathrm{SO}_{4}$ levels were lower in the $0.05-0.60 \mathrm{~m}$ soil depth at 24 months after treatment reapplication than in the previous sampling period (12 months). 
The SOM content was not affected by treatments or sampling periods (Fig. 3). The surface application of lime alone or in association with gypsum increase soil $\mathrm{P}, \mathrm{Ca}$, and $\mathrm{Mg}$ levels throughout the soil profile and $\mathrm{K}$ levels up to $0.40 \mathrm{~m}$ depth, which influenced the BS values (Figs. 3, 4). However, 24 months after the reapplication of the treatments, the $\mathrm{P}$ and $\mathrm{K}$ levels decreased in the soil depth of $0.05-0.10 \mathrm{~m}$ and throughout the soil profile compared to that after 12 months, respectively. The Ca levels increased to a depth of $0.10 \mathrm{~m}$ after 24 months, and $\mathrm{Mg}$ increased below the $0.20-\mathrm{m}$ soil depth, reflecting in greater values of $\mathrm{BS}$.

Crop nutrition and shoot dry matter

The surface application of lime, alone or associated with gypsum, increased macronutrient concentrations in peanut, white oat, and corn leaves compared to the control, with the exceptions of $\mathrm{N}$ in corn and $\mathrm{P}$ in peanut and white oat (Table 3). The surface application of lime and lime + gypsum led to a greater uptake of $\mathrm{Ca}, \mathrm{Mg}$, and $\mathrm{K}$ compared to the control and to gypsum application alone in the crops studied. As observed for $\mathrm{Ca}, \mathrm{Mg}$, and $\mathrm{K}$, the highest $\mathrm{S}$ concentration in the leaves of white oat and corn was found when both soil amendments were applied. The improvements observed in plant nutrition due to liming were reflected in the shoot DM of the three crops.

Peanut, white oat, and corn yield components and kernel/grain yields

Most of the yield components of peanuts, white oat, and corn increased by surface application of lime, alone or associated with gypsum (Table 4). For peanut crop, increases in the number of plants per $\mathrm{m}^{2}$ and the number of pods per plant were the primary factors contributing to the increased pod yield of the crop by liming. In the white oat crop the panicles per $\mathrm{m}^{2}$, number of spikelets per panicles, spikelet fertility and 1000-grain weight were the main components increased by liming, which is reflected directly in the grain yield (Table 4). The numbers of plants per ha and ears per plant of corn were higher with the combination of lime + gypsum followed by liming than those with gypsum alone and the control (Table 4). The grain yield reflected the effects observed in the main yield components.
Forage characteristics, estimated animal stocking rate, and estimated meat production

In both cuts, the forage DM yield, forage crude protein concentration, estimated animal stocking rate, and estimated meat production were improved by lime + gypsum, followed by lime and gypsum alone, when compared to control (Table 5; Fig. 5), more so in the second growing season (2008) than in the first growing season (2007). The low temperatures and low rainfall, mainly between April and June, in the first growing season (2007; Fig. 1) contributed to lower forage DM yield compared to the second growing season (2008) in all treatments and in both cuts. The total estimated meat production was also improved by lime + gypsum treatment compared to control, followed by lime and gypsum alone.

\section{Discussion}

Soil amelioration by surface application of lime and gypsum

Surface liming revealed that the amelioration is not restricted to the most superficial layer of the soil $(0-0.05 \mathrm{~m})$, reaching its effects at the initially proposed depth of $0-0.20 \mathrm{~m}$ (Fig. 2). Additionally, probably due to exchange reactions involving hydroxyl ions $\left(\mathrm{OH}^{-}\right)$and sulfate, the amelioration was improved by gypsum association in the soil $\mathrm{pH}$ at $0-0.05$ and $0.10-0.20 \mathrm{~m}$. The greater availability of $\mathrm{S}^{-\mathrm{SO}_{4}}$ observed at a soil depth of $0-0.20 \mathrm{~m}$ might increase $\mathrm{SO}_{4}$ adsorption in $\mathrm{Fe}$ and $\mathrm{Al}$ oxi-hydroxide and the concomitant release of $\mathrm{OH}^{-}$ions, which react with $\mathrm{H}^{+}$ions in the soil solution, resulting in the formation of $\mathrm{H}_{2} \mathrm{O}$ and increasing $\mathrm{pH}$ values by 0.2 units in these layers (Soratto and Crusciol 2008a). This synergistic effect between lime and gypsum on $\mathrm{H}+\mathrm{Al}$ level was only observed in the layers where the increase in $\mathrm{pH}$ was effective. Compared to liming alone, the application of lime + gypsum increased $\mathrm{pH}$ and reduced the $\mathrm{H}+\mathrm{Al}$ level only in the $0-0.05$ and $0.10-0.20 \mathrm{~m}$ soil layers. The exchangeable $\mathrm{Al}$ was reduced by the application of lime + gypsum in relation to lime alone only in the deepest layer $(0.40-0.60 \mathrm{~m})$. In most soil layers, the effect of combined lime and gypsum application on the potential acidity level $(\mathrm{H}+\mathrm{Al})$ and exchangeable 
Table 3 Influence of surface-applied lime and/or gypsum on nutrient $(\mathrm{N}, \mathrm{P}, \mathrm{K}, \mathrm{Ca}, \mathrm{Mg}$, and $\mathrm{S}$ ) concentration in the leaves and shoot dry matter (DM) of peanut, white oat, and corn cultivated in two growing seasons in a long-term no-till system, and ANOVA significance of these influences

\begin{tabular}{|c|c|c|c|c|c|c|c|}
\hline Treatment & $\mathrm{N}\left(\mathrm{g} \mathrm{kg}^{-1}\right)$ & $\mathrm{P}\left(\mathrm{g} \mathrm{kg}^{-1}\right)$ & $\mathrm{K}\left(\mathrm{g} \mathrm{kg}^{-1}\right)$ & $\mathrm{Ca}\left(\mathrm{g} \mathrm{kg}^{-1}\right)$ & $\operatorname{Mg}\left(\mathrm{g} \mathrm{kg}^{-1}\right)$ & $\mathrm{S}\left(\mathrm{g} \mathrm{kg}^{-1}\right)$ & Shoot DM $\left(\mathrm{t} \mathrm{ha}^{-1}\right)$ \\
\hline \multicolumn{8}{|l|}{ Peanut } \\
\hline Control & $34 \mathrm{a}$ & $4.1 \mathrm{~b}$ & $16 \mathrm{c}$ & $12 \mathrm{~b}$ & $4.9 \mathrm{ab}$ & $3.4 \mathrm{c}$ & $3.1 \mathrm{~b}$ \\
\hline Gypsum & $35 \mathrm{a}$ & $5.0 \mathrm{~b}$ & $17 \mathrm{c}$ & $12 \mathrm{~b}$ & $3.6 \mathrm{~b}$ & $3.8 \mathrm{bc}$ & $3.2 \mathrm{~b}$ \\
\hline Lime & $36 \mathrm{a}$ & $6.5 \mathrm{a}$ & $25 \mathrm{~b}$ & $14 \mathrm{a}$ & $6.3 \mathrm{a}$ & $4.4 \mathrm{ab}$ & $3.7 \mathrm{a}$ \\
\hline Lime + gypsum & $37 \mathrm{a}$ & $6.8 \mathrm{a}$ & $30 \mathrm{a}$ & $15 \mathrm{a}$ & $5.6 \mathrm{a}$ & $4.8 \mathrm{a}$ & $3.8 \mathrm{a}$ \\
\hline LSD & 3.3 & 1.0 & 2.7 & 1.8 & 1.5 & 0.8 & 0.3 \\
\hline \multicolumn{8}{|l|}{ Growing season } \\
\hline $2004 / 2005$ & $34 \mathrm{~b}$ & $4.8 \mathrm{~b}$ & $19 \mathrm{~b}$ & $13 \mathrm{a}$ & $4.8 \mathrm{a}$ & $4.1 \mathrm{a}$ & $3.2 \mathrm{~b}$ \\
\hline $2005 / 2006$ & 37 a & $6.4 \mathrm{a}$ & $25 \mathrm{a}$ & $14 \mathrm{a}$ & $5.4 \mathrm{a}$ & $4.1 \mathrm{a}$ & $3.6 \mathrm{a}$ \\
\hline LSD & 2.1 & 0.7 & 1.9 & 1.3 & 1.0 & 0.6 & 0.2 \\
\hline \multicolumn{8}{|l|}{ ANOVA ( $F$ probability) } \\
\hline Treatment $(\mathrm{T})$ & 0.29 & $<0.01$ & $<0.01$ & 0.04 & 0.02 & $<0.01$ & $<0.01$ \\
\hline Growing season $(\mathrm{G})$ & $<0.01$ & $<0.01$ & $<0.01$ & 0.32 & 0.18 & 0.84 & $<0.01$ \\
\hline $\mathrm{T} \times \mathrm{G}$ & 0.55 & 0.26 & 0.11 & 0.82 & 0.86 & 0.98 & 0.96 \\
\hline \multicolumn{8}{|l|}{ White oat } \\
\hline \multicolumn{8}{|l|}{ Treatment } \\
\hline Control & $35 \mathrm{a}$ & $3.8 \mathrm{c}$ & $25 \mathrm{~b}$ & $10 \mathrm{~b}$ & $2.8 \mathrm{~b}$ & $4.5 \mathrm{c}$ & $4.8 \mathrm{~b}$ \\
\hline Gypsum & $35 \mathrm{a}$ & $4.2 \mathrm{bc}$ & $29 \mathrm{~b}$ & $10 \mathrm{~b}$ & $2.9 \mathrm{~b}$ & $4.9 \mathrm{c}$ & $5.0 \mathrm{~b}$ \\
\hline Lime & $37 \mathrm{a}$ & $4.4 \mathrm{~b}$ & $45 \mathrm{a}$ & $11 \mathrm{a}$ & $3.6 \mathrm{a}$ & $6.3 \mathrm{~b}$ & $5.7 \mathrm{a}$ \\
\hline Lime + gypsum & $37 \mathrm{a}$ & $5.1 \mathrm{a}$ & $42 \mathrm{a}$ & $11 \mathrm{a}$ & $3.6 \mathrm{a}$ & $7.2 \mathrm{a}$ & $5.6 \mathrm{a}$ \\
\hline LSD & 3.4 & 0.6 & 5.3 & 0.9 & 0.6 & 0.6 & 0.5 \\
\hline \multicolumn{8}{|l|}{ Growing season } \\
\hline 2005 & $38 \mathrm{a}$ & $3.8 \mathrm{~b}$ & $29 \mathrm{~b}$ & $10 \mathrm{~b}$ & $2.4 \mathrm{~b}$ & $5.7 \mathrm{a}$ & $5.0 \mathrm{~b}$ \\
\hline 2006 & $35 \mathrm{~b}$ & $4.9 \mathrm{a}$ & $41 \mathrm{a}$ & $11 \mathrm{a}$ & $4.0 \mathrm{a}$ & $5.7 \mathrm{a}$ & $5.6 \mathrm{a}$ \\
\hline LSD & 2.4 & 0.4 & 3.7 & 0.7 & 0.5 & 0.4 & 0.3 \\
\hline \multicolumn{8}{|c|}{ ANOVA (F probability) } \\
\hline Treatment $(\mathrm{T})$ & 0.27 & $<0.01$ & $<0.01$ & $<0.01$ & 0.04 & $<0.01$ & $<0.01$ \\
\hline Growing season $(\mathrm{G})$ & 0.02 & $<0.01$ & $<0.01$ & $<0.01$ & $<0.01$ & 0.91 & $<0.01$ \\
\hline $\mathrm{T} \times \mathrm{G}$ & 0.93 & 0.18 & 0.13 & 0.94 & 0.62 & 0.18 & 0.98 \\
\hline \multicolumn{8}{|l|}{ Corn } \\
\hline \multicolumn{8}{|l|}{ Treatment } \\
\hline Control & $28 \mathrm{~d}$ & $2.4 \mathrm{a}$ & $23 \mathrm{~d}$ & $2.7 \mathrm{~d}$ & $2.2 \mathrm{c}$ & $1.6 \mathrm{~d}$ & $8.8 \mathrm{c}$ \\
\hline Gypsum & $30 \mathrm{c}$ & $2.4 \mathrm{a}$ & $25 \mathrm{c}$ & $2.9 \mathrm{c}$ & $2.1 \mathrm{~d}$ & $1.8 \mathrm{c}$ & $8.8 \mathrm{c}$ \\
\hline Lime & $32 \mathrm{~b}$ & $2.4 \mathrm{a}$ & $27 \mathrm{~b}$ & $4.0 \mathrm{~b}$ & $3.3 \mathrm{a}$ & $2.0 \mathrm{~b}$ & $10.4 \mathrm{~b}$ \\
\hline Lime + gypsum & $34 \mathrm{a}$ & $2.3 \mathrm{a}$ & $29 \mathrm{a}$ & $4.7 \mathrm{a}$ & $3.1 \mathrm{~b}$ & $2.3 \mathrm{a}$ & $12.9 \mathrm{a}$ \\
\hline LSD & 1.2 & 0.2 & 1.2 & 0.1 & 0.1 & 0.1 & 1.0 \\
\hline \multicolumn{8}{|l|}{ Growing season } \\
\hline $2006 / 2007$ & $30 \mathrm{~b}$ & $2.4 \mathrm{~b}$ & $25 \mathrm{~b}$ & $3.4 \mathrm{~b}$ & $2.6 \mathrm{~b}$ & $1.9 \mathrm{~b}$ & $8.0 \mathrm{~b}$ \\
\hline $2007 / 2008$ & $33 \mathrm{a}$ & $2.5 \mathrm{a}$ & $28 \mathrm{a}$ & $3.7 \mathrm{a}$ & $2.7 \mathrm{a}$ & $2.1 \mathrm{a}$ & $12.0 \mathrm{a}$ \\
\hline LSD & 0.8 & 0.2 & 0.8 & 0.1 & 0.1 & 0.1 & 0.8 \\
\hline \multicolumn{8}{|l|}{ ANOVA (F probability) } \\
\hline Treatment $(\mathrm{T})$ & $<0.01$ & 0.12 & $<0.01$ & $<0.01$ & $<0.01$ & $<0.01$ & $<0.01$ \\
\hline Growing season $(\mathrm{G})$ & $<0.01$ & 0.04 & $<0.01$ & $<0.01$ & $<0.01$ & 0.02 & $<0.01$ \\
\hline
\end{tabular}


Table 3 continued

\begin{tabular}{llllllcc}
\hline Treatment & $\mathrm{N}\left(\mathrm{g} \mathrm{kg}^{-1}\right)$ & $\mathrm{P}\left(\mathrm{g} \mathrm{kg}^{-1}\right)$ & $\mathrm{K}\left(\mathrm{g} \mathrm{kg}^{-1}\right)$ & $\mathrm{Ca}\left(\mathrm{g} \mathrm{kg}^{-1}\right)$ & $\mathrm{Mg}\left(\mathrm{g} \mathrm{kg}^{-1}\right)$ & $\mathrm{S}\left(\mathrm{g} \mathrm{kg}^{-1}\right)$ & Shoot DM $\left(\mathrm{t} \mathrm{ha}^{-1}\right)$ \\
\hline $\mathrm{T} \times \mathrm{G}$ & 0.96 & 0.99 & 0.90 & 0.35 & 0.99 & 0.91 & 0.39 \\
\hline
\end{tabular}

LSD Least significant difference

Means followed by different letters in the same column differ significantly according to the LSD test $(p \leq 0.05)$

Al was not statistically different to the effect of lime alone (Fig. 2). Costa and Rosolem (2007) reported a positive effect of liming on the concentration of exchangeable bases and the reduction of toxic $\mathrm{Al}$ levels, but proportional changes in the soil $\mathrm{pH}$ did not occur.

Our results showed the gypsum effects on $\mathrm{S}_{-} \mathrm{SO}_{4}$ availability through the soil profile (Fig. 2), due to its composition that contains $17 \% \mathrm{~S}$. In addition, the greatest $\mathrm{S}-\mathrm{SO}_{4}$ availability in the soil from depths of $0-0.20 \mathrm{~m}$ with gypsum + lime application indicates effect of soil $\mathrm{pH}$ on sulfate availability (Fig. 2). The lower soil S-SO $\mathrm{SO}_{4}$ levels in the $0.05-0.60 \mathrm{~m}$ soil depth after 24 months than after 12 months occurred because the $\mathrm{SO}_{4}$ produced by gypsum dissociation had a greater displacement capacity in the soil profile, with effects below the 0.20 -m soil depth.

The long period required to reduce the acidity within the deeper layers of soil (a depth of $0.60 \mathrm{~m}$ by 4 years from the experiment implementation) (Fig. 2) could be explained by the low mobility and solubility of carbonate in soil (Alcarde 1992). However, this period can vary mainly due to the inherent characteristics of the soil acidity amendment, the attributes of the soil, and the amount of rain that fell during the amendment reaction time (Amaral et al. 2004). The formation and preservation of pore spaces of biological or chemical origin are extremely important for the percolation of lime particles into deeper layers of soil (Gatiboni et al. 2003).

The lack of positive effects on SOM by lime and/or gypsum application (Fig. 3) is related to the lower amount of the shoot DM of peanut (3.1-3.8 $\left.\mathrm{t} \mathrm{ha}^{-1}\right)$ and white oat (4.8-5.6 $\left.\mathrm{tha}^{-1}\right)$ remaining on the soil surface during the sampling periods (Table 3 ). These amounts of biomass, mainly from legumes (peanut) and C3 annual winter grasses (white oat), which accelerate straw decomposition under tropical conditions, can hardly increase the total SOM in the short term (Briedis et al. 2012a, b; Castro et al. 2015; Costa and Crusciol 2016).
The surface application of lime and lime + gypsum was sufficient to increase soil $P$ levels throughout the soil profile (Fig. 3). In these variable charged tropical soils, as in most of the soils of the Brazilian Cerrado and African Savanna, the net negative charges may positively influence the bioavailability of soil $\mathrm{P}$ due to decreases in phosphate adsorption by repulsion mechanisms (Barrow 1985). In addition, with higher availability of $\mathrm{OH}^{-}$in the soil solution, $\mathrm{P}$ adsorption is lower because both ions $\left(\mathrm{OH}^{-}\right.$and $\left.\mathrm{PO}_{4}{ }^{2-}\right)$ compete for the same adsorption sites. According to Sato and Comerford (2005), the $\mathrm{P}$ adsorption mechanism is governed mainly by changes in soil $\mathrm{pH}$; furthermore, the authors indicated that an increase in $\mathrm{pH}$ from 4.7 to 5.9 can reduce the adsorption of this nutrient in soil colloids by as much as $21 \%$. Also, an effect of gypsum alone on the availability of $\mathrm{P}$ was also observed up to $0.10 \mathrm{~m}$, possibly due to the displacement mechanism of the $\mathrm{H}_{2} \mathrm{PO}_{4}{ }^{-}$by $\mathrm{SO}_{4}{ }^{2-}$ (Rampim et al. 2013). The application of gypsum increased the concentration of $\mathrm{S}_{-} \mathrm{SO}_{4}$ and the formation of the $\mathrm{AlSO}_{4}{ }^{+}$ion pair, reducing the forms of $\mathrm{P}-\mathrm{Al}$ and, with this, there was an increase of $\mathrm{P}$ in the soil. However, 24 months after the surface reapplication of the treatments, the effect on the availability of $\mathrm{P}$ was observed only at depths of $0.05-0.10 \mathrm{~m}$, because seeding fertilizer containing $\mathrm{P}$ is deposited at those depths, causing the accumulation of that nutrient over years of cultivation (Pariz et al. 2016, 2017a).

The surface application of lime and lime + gypsum was sufficient to increase soil $\mathrm{K}$ levels up to a depth of $0.40 \mathrm{~m}$ (Fig. 3). The application of lime alone promoted a higher $\mathrm{K}$ content in the uppermost soil layer $(0-0.10 \mathrm{~m})$. Liming increases $\mathrm{pH}$-dependent negative charges (Quaggio et al. 1982) and alters the charge by divalent cations $(\mathrm{Ca}$ and $\mathrm{Mg}$ ) by forming complexes with water-soluble organic ligands that are present in crop residues (Miyazawa et al. 1993), those free charge would be occupied by $\mathrm{K}$ from fertilizers and crop residues, increasing exchangeable $\mathrm{K}$ levels mainly in the upper soil layers (Caires et al. 1998). The 
Table 4 Influence of surface-applied lime and/or gypsum on yield components, pod yield and peanut hulled-kernel yield, and white oat and corn grain yield cultivated in two growing seasons in a long-term no-till system, and ANOVA significance of these influences

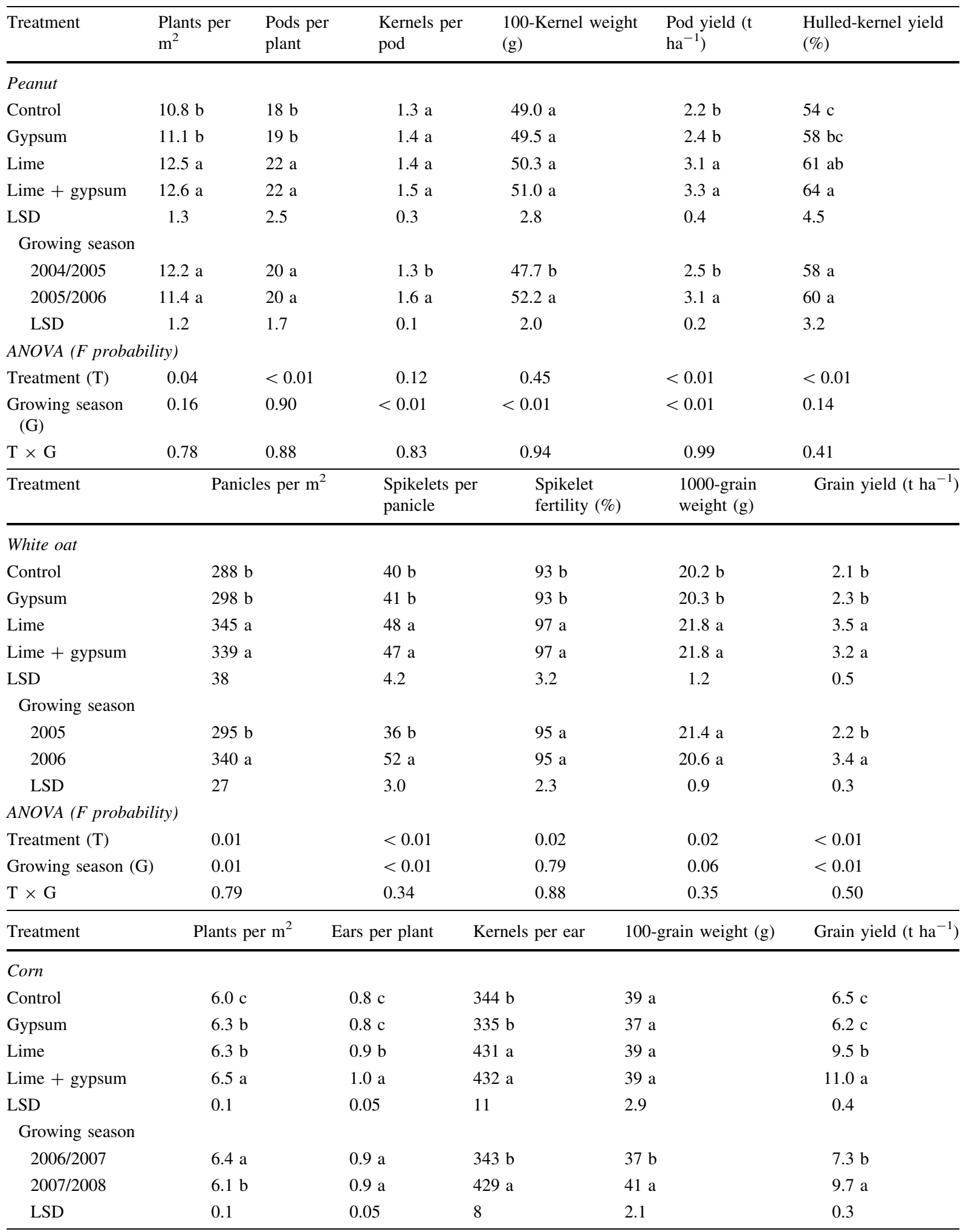


Table 4 continued

\begin{tabular}{lcclll}
\hline Treatment & Plants per $\mathrm{m}^{2}$ & Ears per plant & Kernels per ear & 100-grain weight $(\mathrm{g})$ & $\mathrm{Grain} \mathrm{yield}\left(\mathrm{t}\right.$ ha $\left.^{-1}\right)$ \\
\hline ANOVA (F probability) & & & & & $<0.01$ \\
Treatment $(\mathrm{T})$ & $<0.01$ & $<0.01$ & $<0.01$ & 0.40 & $<0.01$ \\
Growing season $(\mathrm{G})$ & $<0.01$ & 0.90 & $<0.01$ & $<0.01$ & 0.59 \\
$\mathrm{~T} \times \mathrm{G}$ & 0.93 & 0.13 & 0.25 & 0.99 & \\
\hline
\end{tabular}

LDS least significant difference

Means followed by different letters in the same column differ significantly according to the LSD test $(p \leq 0.05)$

Table 5 Influence of surface-applied lime and/or gypsum on the forage dry matter yield (FDMY), forage crude protein concentration (CP), estimated animal stocking rate (EASR) and estimated meat production (EMP) in pasture of palisade grass after intercropping with corn in two growing seasons in a longterm no-till system and ANOVA significance

\begin{tabular}{|c|c|c|c|c|c|c|c|c|c|}
\hline \multirow[t]{2}{*}{ Treatment } & \multicolumn{2}{|c|}{ FDMY $\left(\mathrm{t} \mathrm{ha}^{-1}\right)$} & \multicolumn{2}{|l|}{$\mathrm{CP}(\%)$} & \multicolumn{2}{|c|}{$\operatorname{EASR}\left(\mathrm{AU} \mathrm{ha}^{-1}\right)^{\mathrm{b}}$} & \multicolumn{2}{|c|}{$\operatorname{EMP}\left(\mathrm{kg} \mathrm{ha}^{-1}\right)^{\mathrm{c}}$} & \multirow[t]{2}{*}{ Total } \\
\hline & $\begin{array}{l}\text { First } \\
\text { cut }^{\mathrm{a}}\end{array}$ & $\begin{array}{l}\text { Second } \\
\text { cut }^{\mathrm{a}}\end{array}$ & $\begin{array}{l}\text { First } \\
\text { cut }^{\mathrm{a}}\end{array}$ & $\begin{array}{l}\text { Second } \\
\text { cut }^{\mathrm{a}}\end{array}$ & $\begin{array}{l}\text { First } \\
\text { cut }^{\mathrm{a}}\end{array}$ & $\begin{array}{l}\text { Second } \\
\text { cut }^{\mathrm{a}}\end{array}$ & $\begin{array}{l}\text { First } \\
\text { cut }^{\mathrm{a}}\end{array}$ & $\begin{array}{l}\text { Second } \\
\text { cut }^{\mathrm{a}}\end{array}$ & \\
\hline Control & $3.0 \mathrm{~d}$ & $3.4 \mathrm{~d}$ & $9.0 \mathrm{~d}$ & $8.4 \mathrm{~d}$ & $2.2 \mathrm{~d}$ & $2.6 \mathrm{~d}$ & $68.5 \mathrm{~d}$ & $73.9 \mathrm{~d}$ & $142.4 \mathrm{~d}$ \\
\hline Gypsum & $3.6 \mathrm{c}$ & $4.2 \mathrm{c}$ & $9.5 \mathrm{c}$ & $9.1 \mathrm{c}$ & $2.7 \mathrm{c}$ & $3.1 \mathrm{c}$ & $86.2 \mathrm{c}$ & $97.4 \mathrm{c}$ & $183.6 \mathrm{c}$ \\
\hline Lime & $6.2 \mathrm{~b}$ & $7.7 \mathrm{~b}$ & $12.4 \mathrm{~b}$ & $11.7 \mathrm{~b}$ & $4.7 \mathrm{~b}$ & $5.8 \mathrm{~b}$ & $163.5 \mathrm{~b}$ & $204.9 \mathrm{~b}$ & $368.4 \mathrm{~b}$ \\
\hline Lime + gypsum & $7.6 \mathrm{a}$ & $9.3 \mathrm{a}$ & $13.3 \mathrm{a}$ & $12.3 \mathrm{a}$ & $5.7 \mathrm{a}$ & $7.0 \mathrm{a}$ & $206.3 \mathrm{a}$ & $256.9 \mathrm{a}$ & $463.2 \mathrm{a}$ \\
\hline LSD & 0.5 & 0.3 & 0.4 & 0.6 & 0.2 & 0.2 & 11.6 & 16.8 & 35.2 \\
\hline \multicolumn{10}{|l|}{ Growing season } \\
\hline 2007 & $4.5 \mathrm{~b}$ & $5.4 \mathrm{~b}$ & $11.1 \mathrm{a}$ & $10.0 \mathrm{a}$ & $3.3 \mathrm{~b}$ & $4.1 \mathrm{~b}$ & $114.0 \mathrm{~b}$ & $138.4 \mathrm{~b}$ & $252.4 \mathrm{~b}$ \\
\hline 2008 & $5.7 \mathrm{a}$ & $6.9 \mathrm{a}$ & $11.0 \mathrm{a}$ & $9.6 \mathrm{a}$ & $4.3 \mathrm{a}$ & $5.2 \mathrm{a}$ & $148.2 \mathrm{a}$ & $178.1 \mathrm{a}$ & $326.3 \mathrm{a}$ \\
\hline LSD & 0.3 & 0.3 & 0.4 & 0.5 & 0.2 & 0.2 & 8.0 & 12.0 & 24.8 \\
\hline \multicolumn{10}{|c|}{ ANOVA ( $F$ probability) } \\
\hline Treatment $(\mathrm{T})$ & $<0.01$ & $<0.01$ & $<0.01$ & $<0.01$ & $<0.01$ & $<0.01$ & $<0.01$ & $<0.01$ & $<0.01$ \\
\hline $\begin{array}{l}\text { Growing season } \\
\text { (G) }\end{array}$ & $<0.01$ & $<0.01$ & 0.12 & 0.54 & $<0.01$ & $<0.01$ & $<0.01$ & $<0.01$ & $<0.01$ \\
\hline $\mathrm{T} \times \mathrm{G}$ & $<0.01$ & $<0.01$ & 0.65 & 0.90 & $<0.01$ & $<0.01$ & $<0.01$ & $<0.01$ & $<0.01$ \\
\hline
\end{tabular}

LSD least significant difference

Means followed by different letters in the column differ statistically according to the LSD test $(p \leq 0.05)$

${ }^{a}$ First and second cut in June and August, respectively

${ }^{\mathrm{b}} 1 \mathrm{AU}$ (animal unit) $=450 \mathrm{~kg}$ of body weight

${ }^{\mathrm{c}}$ Estimated meat production $=\mathrm{kg}$ of body weight gain $($ cattle) per ha (estimated) $\times 52 \%$ of carcass yield

greater K cycling by the crop with lime application can have increased $\mathrm{K}$ content at uppermost soil layers, as was also reported by Caires et al. (1998). Otherwise, the combination of the two soil amendments is a viable technique for increasing $\mathrm{K}$ availability in subsoil layers (below the 0.20-m layer) (Table 3; Fig. 3). The increase in the availability of $\mathrm{K}$ at these depths may result from the formation of ionic complexes $\left(\mathrm{K}_{2} \mathrm{SO}_{4}\right)$ in the surface layer, intensifying the leaching process and increasing the $\mathrm{K}$ availability as a consequence of $\mathrm{K}_{2} \mathrm{SO}_{4}$ dissociation (Rampim et al. 2011). Regarding sampling time, $\mathrm{K}$ content decreased throughout the soil profile after 24 months compared to that after 12 months, in part due to the exportation of peanut and white oat crops.

The surface application of lime, alone or associated with gypsum, increased the exchangeable $\mathrm{Ca}$ and $\mathrm{Mg}$ levels up to a depth of $0.60 \mathrm{~m}$ (Fig. 4). After 

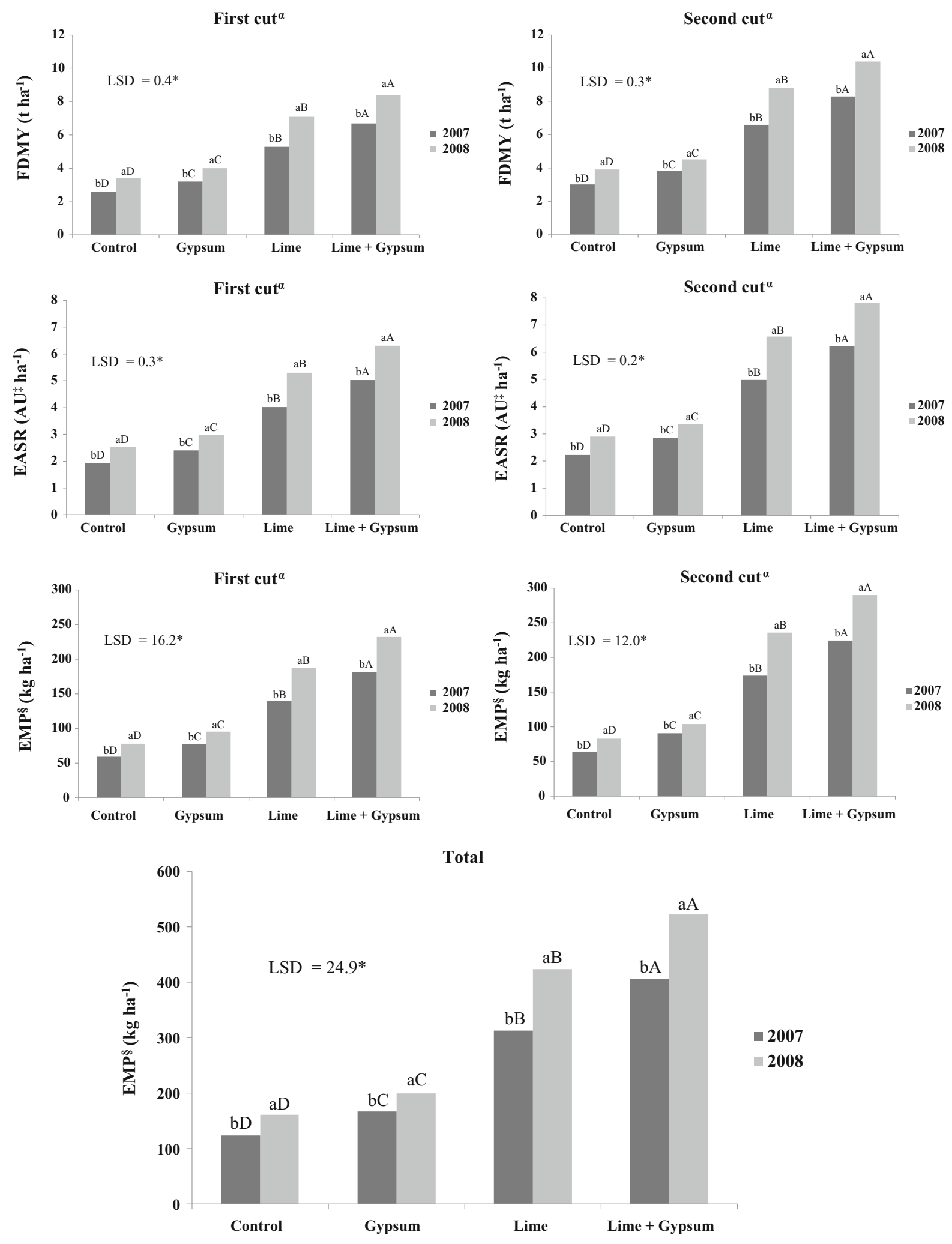
४Fig. 5 Significant interactions on forage dry matter yield (FDMY), estimated animal stocking rate (EASR) and estimated meat production (EMP) in the pasture of palisade grass after intercropping with corn in two growing seasons in a long-term no-till system influenced by surface-applied lime and/or gypsum treatments. ${ }^{\alpha}$ First and second cut in June and August, respectively. ${ }^{*} 1 \mathrm{AU}$ (animal unit) $=450 \mathrm{~kg}$ of body weight. ${ }^{\S} \mathrm{EMP}=\mathrm{kg}$ of body weight gain (cattle) per ha (estimated) $\times 52 \%$ of carcass yield. *Different lowercase and uppercase letters following the values indicate significantly differences according to the LSD (least significant difference) test $(p \leq 0.05)$, between growing seasons and treatments, respectively

24 months, Ca increased to a depth of $0.10 \mathrm{~m}$ compared to that after 12 months, and $\mathrm{Mg}$ increased below the $0.20-\mathrm{m}$ soil depth. This occurred because the application of lime was performed superficially, causing $\mathrm{Ca}$ accumulation at the soil surface. The changes in $\mathrm{K}, \mathrm{Ca}$ and $\mathrm{Mg}$ levels influenced the values of BS (Figs. 3, 4). The results related to the surface application of lime and lime + gypsum were verified throughout the soil profile, with greater effects 24 months after treatment reapplication. The observed increases are related to the increased concentrations of $\mathrm{Ca}, \mathrm{Mg}$ and $\mathrm{K}$ cations from the added fertilizer in the colloidal complex, as a result of the extrusion of $\mathrm{H}^{+}$ from the surface of the colloids and neutralization of the exchangeable $\mathrm{Al}$, as reported by Soratto and Crusciol (2008a).

Plant nutrition, yield components, and kernel/grain yields of peanut, white oat, and corn

The higher concentration of $\mathrm{N}$ in corn plant leaves (Table 3) may be a consequence of the higher availability of $\mathrm{N}$ in the soil treated with lime + gypsum or lime alone. According to Rosolem et al. (2003), alleviation of soil acidity affects the biological soil processes that govern the intensity of mineralization and nitrification, increasing $\mathrm{N}$ bioavailability and ion contact with the root system. This pronounced effect of $\mathrm{N}$ concentration in corn plant leaves are linked to the higher demand by this crops. It is important to emphasize that regardless of soil amendment application, the $\mathrm{N}$ concentration in the corn leaves was within the range considered adequate for this crop; however, the leaves of peanut and white oat exhibited values within and higher than the range considered sufficient, respectively (Ambrosano et al. 1997; Cantarella et al. 1997).
Due to the higher $P$ availability in the limeamended soil, $P$ concentration in the leaves of peanut and white oat increased (Table 3). Similar results were reported by Soratto and Crusciol (2008c), which showed a positive effect of liming on $P$ uptake by black oat plants. As confirmed by our results and those of Viviani et al. (2010), the availability of P in Oxisols is determined by the soil acidity level. Due to the beneficial effects of the lime + gypsum combination on increasing $\mathrm{S}_{-} \mathrm{SO}_{4}$ levels in the soil (Fig. 2), the highest $P$ concentration was observed in white oat leaves. The competitive adsorption between sulfate and phosphate may reduce $P$-specific adsorption, thus increasing nutrient bioavailability for white oat plants, which are highly dependent on $P$ (Nakagawa and Rosolem 2005). Furthermore, in the case of the white oat and corn crops, all treatments showed $P$ values within the desired range, except for the peanut crop, for which the recorded nutrient concentrations were above the maximum amount considered adequate (Cantarella et al. 1997; Ambrosano et al. 1997).

It is important to note that even though there was no higher concentration of macronutrients in leaves of some crops, the use of lime and lime + gypsum increased the DM of plants, and it could be inferred that there was a higher absorption and accumulation of these nutrients, causing the dilution effect. Contrast with this inference, the fact of this increase in DM, were in the average of treatments of lime and lime + gypsum 21,18 and $32 \%$ higher in relation to the control, respectively (Table 3 ).

The greater uptake of $\mathrm{Ca}, \mathrm{Mg}$, and $\mathrm{K}$ in the crops studied (Table 3) was probably due to the effects of both soil amendments on soil fertility improvement. Despite the positive results obtained with soil amendment application, the treatments did not influence the critical $\mathrm{Ca}$ and $\mathrm{Mg}$ concentrations in leaves. For all crops studied, the concentrations were above the adequate range for the crops, indicating that these nutrients had not otherwise limited the development of the crops studied (Cantarella et al. 1997; Ambrosano et al. 1997).

The highest $\mathrm{S}$ concentration in the leaves of white oat and corn was found when both soil amendments were applied (Table 3 ). This effect is probably related to the high $\mathrm{S}_{-} \mathrm{SO}_{4}$ levels at depths from 0 to $0.20 \mathrm{~m}$ in soil treated with lime + gypsum (Fig. 2). Soratto and Crusciol (2008c) reported a positive effect of gypsum, 
increasing the $\mathrm{S}$ concentrations in the leaves of black oat plants, wherein the input was considered an important source of this nutrient. However, regardless of the treatments, the concentration of $\mathrm{S}$ in the leaves of the three crops was also above the range considered adequate for each crop (Cantarella et al. 1997; Ambrosano et al. 1997).

The improvements observed in plant nutrition due to liming were reflected in the shoot DM of the three crops (Table 3). Positive results with gypsum addition in lime-amended soil were only observed for corn, promoting greater shoot DM compared to the other treatments. According to Caires et al. (2011), the effect of gypsum was probably related to the enhanced absorption of $\mathrm{Ca}$ by the corn plants, whereas in the case of legumes, the authors did not find this effect. Even though the present study indicated beneficial effects of the surface application of lime + gypsum with respect to increasing concentrations of $\mathrm{Ca}$ in the leaves of peanut plants, this benefit was not reflected in shoot $\mathrm{DM}$, which may be related to the $\mathrm{Ca} / \mathrm{Mg}$ ratio in the soil. Regarding differences between the growing seasons, higher shoot DM values for peanut, white oat and corn were obtained in the second growing season. The plants of these three species also exhibited higher macronutrient concentrations in their leaves in the second growing season.

As a consequence of the improved chemical properties of soil due to lime and gypsum application (Figs. 2, 3 and 4), the yield components of peanuts, white oat and corn increased (Table 4). The highest pod yield of a peanut crop was mainly due to the increased availability of $\mathrm{Ca}$ in the soil (Fig. 4) because $\mathrm{Ca}$ plays a fundamental role in reducing the abortion rate of fertilized ovules (Colwell and Brady 1945). In addition, because translocation of this nutrient from other parts of the plant does not occur to an appreciable extent, its availability in the soil is essential. The higher availability of $\mathrm{Ca}$ in the soil with gypsum improved the percentage of hulledkernel yield, which is directly related to the normal fruit development.

Regarding the white oat crop, the observed increase in the yield components (panicles per $\mathrm{m}^{2}$, number of spikelets per panicles, spikelet fertility and 1000-grain weight) due to liming (Table 4) is related to the reduction of toxic aluminum (Fig. 2) because the crop is susceptible to damage caused by this element, mainly in its root system, providing a favorable environment for better plant nutrition (Table 3), which is reflected directly in the grain yield. Crusciol et al. (2016b) also observed positive results regarding soil acidity amelioration in an NT system. These authors reported that the number of panicles per square meter and the grain yield of rice increased because of surface liming.

The largest number of plants per ha and ears per plant of corn lime + gypsum followed by liming (Table 4) indicates that the improvements in the soil chemical characteristics positively influenced plant establishment and initial development from the phenological phase of three to five fully developed leaves, the stage at which potential ears begin to be determined (Crusciol et al. 2013). The grain yield reflected the effects observed in the yield components. Therefore, the combination of both soil amendments was considered a viable technique to improve the productivity capacity of acid tropical soils managed under conservative practices. According Bossolani et al. (2018), grain yield is positively influenced by the reapplication of lime and gypsum, and the combination of the lime dose of $3243 \mathrm{~kg} \mathrm{ha}^{-1}$ with gypsum doses between 1500 and $3000 \mathrm{~kg} \mathrm{ha}^{-1}$ provides the highest yield for corn sole crop $\left(8568 \mathrm{~kg} \mathrm{ha}^{-1}\right)$. However, corn intercropped with palisade grass, associated with similar lime and gypsum dose (3031 and 1500-3000 kg ha ${ }^{-1}$, respectively), promoted better soil conditions and consequently higher corn nutrition, resulting in higher grain yield $\left(11,237 \mathrm{~kg} \mathrm{ha}^{-1}\right)$, that is, $23.75 \%$ increase compared to corn sole crop. Thus, these authors concluded that the corn intercropped with palisade grass provided superior condition to corn sole crop, where the utilization of $\mathrm{N}$ applied to the system and the availability of $\mathrm{Ca}$ and $\mathrm{Mg}$, in addition to the possible greater acidity correction and neutralization of $\mathrm{Al}^{3+}$ in the deeper layers of soil, provided a better development of crop, being able to exploit its productive potential.

Note that the grain production in the subtropical region does not always benefit from lime and gypsum application, particularly under water deficiency, highlighting the importance of studies in different climatic conditions. In the present study in a tropical region, liming always benefited grain production, even in years with a regular rainfall distribution. For gypsum, this fact provides greater safety for grain production by mitigating losses under a water deficit. 
Forage yield and quality and estimated meat production

It can be inferred that surface application of lime alone or lime + gypsum in the long-term NT system of tropical agriculture in the Brazilian Cerrado using corn intercropped with palisade grass increased forage DM yield after corn harvest compared to no amendment application (control) or application of gypsum alone treatments (Table 5; Fig. 5). This occurred because this tropical perennial grass has a low tolerance to acidic soils (Pariz et al. 2016; 2017a), mainly with a BS below 60-70\% in the topsoil in our case (Fig. 4). Consequently, the lower forage DM yield decreased the estimated animal stocking rate and estimated meat production. This result demonstrates the importance of lime and gypsum applications in annual crop rotations with pastures in tropical NT system, and the best results depend on the agricultural amendments applied and reapplied in the crop rotation. In subtropical Brazilian regions, the surface lime (application or reapplication) in an ICL system (soybean-beef cattle) also increased the forage DM yield [mix of black oat + Italian ryegrass (Lolium multiflorum L.)] and reduced long-term soil acidification, with a higher BS and lower $\mathrm{Al}$ saturation, mainly in grazed areas compared to non-grazed areas (Martins et al. 2014a; 2014b; 2016).

According to Costa et al. (2005), the optimal temperature range for palisade grass development was between 30 and $35^{\circ} \mathrm{C}$, and its growth was highly reduced between 10 and $15{ }^{\circ} \mathrm{C}$. In our experiment, we observed average temperatures between 15 and $20{ }^{\circ} \mathrm{C}$ from May to August. However, the forage DM yield (2.99-7.56 $\mathrm{t} \mathrm{ha}^{-1}$ in the first cut and 3.43-9.33 $\mathrm{tha}^{-1}$ in the second cut) in this study (Table 5; Fig. 5) can be considered high during this dry season (winter/spring). Thus, in an ICL system, the forage DM can be used as an index for mechanical cutting or in the fields for grazing by animals (Pariz et al. 2011) and to increase the animal stocking rate, meat production and profitability for the farmer. Typically, during this time of the year (June to September), the availability of forage in areas with dry winters is limited (Borghi et al. 2013). Consequently, the animal stocking rate is low (less than 1.0 animal unit per ha $=450 \mathrm{~kg}$ of body weight per ha), and these animals usually lose weight. Our estimated animal stocking rate provided 2.2-7.0 animal units per ha, and as a function of fodder quantity and quality, the animals can gain weight during dry winters, as also demonstrated by Crusciol et al. (2016a). Sowing tropical forage after harvesting corn grain also does not provide sufficient fodder during the autumn, winter and part of the spring in regions with dry winters such as the Brazilian Cerrado or African Savanna. However, in this intercropping system, the rainfalls after the corn is harvested (in April and May), allowing for the adequate development of palisade grass.

The observed 2-year-average crude protein concentration of approximately $9.6-11.1 \%$ was higher than the crude protein concentration of $7.0 \%$ reported by van Soest (1994) as the minimum concentration required for maintaining microbial populations in the rumen of cattle. However, the higher crude protein concentration in the forage could lead to higher average daily weight gain in beef cattle. Therefore, considering the higher forage DM yield associated with higher crude protein concentrations, the lime + gypsum and lime application/reapplication treatments could provide higher cattle meat production per ha, compared to gypsum application/reapplication and control (no application/reapplication) treatments (Fig. 5).

\section{Economics}

The control treatment (no surface-applied lime and gypsum) resulted in a negative net profit for peanut and white oat crops in both growing seasons, as well as promoted the lowest total and mean net profits (Table 6). Isolated applications of gypsum or lime increased total net profit by 41 and $322 \%$ over control treatment. However, the surface application of lime + gypsum resulted in the highest total (US\$ $3891 \mathrm{ha}^{-1}$ ) and mean (US\$ $973 \mathrm{ha}^{-1}$ ) net profits, which were $470 \%$ higher than the control and $35 \%$ higher than the lime alone. These economic results demonstrate the importance of lime and gypsum practices in annual crop rotations with pastures in tropical NT system.

An ICL system using corn intercropped with palisade grass is a good option in the tropical agricultural system because, in addition to corn grain produced in summer/autumn, farmers can use the forage DM production of palisade grass for animal fodder in winter/spring. The palisade grass pasture in winter/spring provided higher net profit than did white 
Table 6 Influence of surface-applied lime and/or gypsum on economic evaluation of peanut, white oat, corn intercropped with palisade grass, and palisade grass pasture in four growing seasons in a long-term no-till system

\begin{tabular}{|c|c|c|c|c|c|c|c|c|c|c|}
\hline Treatment & $\begin{array}{c}\text { Peanut } \\
2004 / \\
2005\end{array}$ & $\begin{array}{l}\text { White } \\
\text { oat } \\
2005\end{array}$ & $\begin{array}{l}\text { Peanut } \\
2005 / \\
2006\end{array}$ & $\begin{array}{l}\text { White } \\
\text { oat } \\
2006\end{array}$ & $\begin{array}{l}\text { Corn } \\
2006 / \\
2007\end{array}$ & $\begin{array}{l}\text { Pasture } \\
\text { (Meat) } \\
2007\end{array}$ & $\begin{array}{l}\text { Corn } \\
2007 / \\
2008\end{array}$ & $\begin{array}{l}\text { Pasture } \\
\text { (Meat) } \\
2008\end{array}$ & Total $^{\mathrm{d}}$ & Mean $^{\mathrm{e}}$ \\
\hline \multicolumn{11}{|l|}{$\operatorname{Cost}\left(U S \$ h a^{-1}\right)^{a}$} \\
\hline Control & 753 & 214 & 753 & 214 & 598 & 112 & 598 & 149 & 3392 & 848 \\
\hline Gypsum & 811 & 214 & 753 & 214 & 598 & 136 & 598 & 180 & 3504 & 876 \\
\hline Lime & 809 & 214 & 753 & 214 & 598 & 246 & 598 & 326 & 3759 & 940 \\
\hline Lime + Gypsum & 866 & 214 & 753 & 214 & 598 & 298 & 598 & 395 & 3935 & 984 \\
\hline \multicolumn{11}{|c|}{ Gross revenue $\left(U S \$ h a^{-1}\right)^{b}$} \\
\hline Control & 558 & 142 & 710 & 213 & 753 & 287 & 1039 & 373 & 4075 & 1019 \\
\hline Gypsum & 612 & 155 & 780 & 232 & 770 & 389 & 1064 & 461 & 4464 & 1116 \\
\hline Lime & 792 & 241 & 1007 & 362 & 1065 & 725 & 1471 & 980 & 6644 & 1661 \\
\hline Lime + gypsum & 848 & 221 & 1080 & 331 & 1344 & 938 & 1855 & 1209 & 7826 & 1957 \\
\hline \multicolumn{11}{|c|}{ Net profit $\left(U S \$ h a^{-1}\right)^{\mathrm{c}}$} \\
\hline Control & -195 & -72 & -43 & -1 & 154 & 175 & 441 & 224 & 683 & 171 \\
\hline Gypsum & -198 & -59 & 26 & 19 & 172 & 253 & 466 & 281 & 960 & 240 \\
\hline Lime & -17 & 28 & 254 & 148 & 467 & 479 & 873 & 653 & 2885 & 721 \\
\hline Lime + gypsum & -17 & 7 & 326 & 117 & 746 & 640 & 1257 & 814 & 3891 & 973 \\
\hline
\end{tabular}

${ }^{a}$ Means costs and production costs of crops; the only difference was the lime and gypsum used before the peanut crop (November 2004) and pasture costs as a function of the animal stocking rate

${ }^{\mathrm{b}}$ Gross revenue $=\mathrm{kg}$ of peanut (pod yield $\times$ hulled-kernel yield), white oat and corn grain yield and estimated meat production per ha $\times$ US\$ 0.28, US\$ 0.08, US\$ 0.14 and US\$ 2.23, respectively. We used the Brazilian national average price from the past 5 years and converted these values to dollars (US\$) (Agrolink 2018)

${ }^{\mathrm{c}}$ Net profit is the realization per ha, which was calculated using the formula: gross revenue - cost

${ }^{\mathrm{d}}$ Total $=$ sum of all growing seasons

${ }^{\mathrm{e}}$ Mean $=$ mean per growing season

oat (Table 6). Surface lime + gypsum application resulted in higher net profits as a function of the higher forage DM, crude protein concentration (which yields a greater body weight gain for beef cattle), estimated animal stocking rate and estimated meat production (Table 5; Fig. 5).

\section{Conclusions}

Surface liming was found to be an effective practice for reducing the exchangeable acidity and $\mathrm{Al}$ concentration extending to a depth of $0.60 \mathrm{~m}$. Gypsum application increased $\mathrm{Ca}^{2+}$ levels through the soil profile. There was a positive effect of liming (with or without gypsum) on the nutrient acquisition of peanut, white oat and corn crops, producing higher pod and grain yield than in the absence of soil amendments or with gypsum alone. The surface application of lime + gypsum also increased the forage DM yield, estimated meat production of the corn-palisade grass intercropping and economic performance during four growing seasons and can improve the long-term food production of tropical agriculture with high soil acidity.

We also emphasize that lime and gypsum were applied and reapplied together (i.e., in the same months). The usual recommendation is to first apply lime and to then apply gypsum in the next year due the solubility of the inputs. Therefore, our research demonstrated that even with simultaneous application of lime and gypsum, the agronomic and economic results were positive. In addition, besides the soil chemical improvement, the use of water storage in subsoil can also support increases in crop yields, forage production and quality. Therefore, in future 
research with lime and gypsum, water storage in subsoils and the root systems of crops must be evaluated because it can explain the positive crop yield results.

Our results may have great agronomic importance in many regions of the world, mainly in tropical regions characterized mostly by soils exhibiting variable charge and low fertility, low forage production in the dry season, and low cattle production due to low forage supply because the pastures are usually degraded. Therefore, annual crop rotation with pasture in tropical NT system using corn intercropped with palisade grass is a promising option for farmers, and lime (mainly with gypsum) is required to maximize sustainability and profit in the system. The ICL system can diversify the sources of farm income, producing grain and meat in the same agricultural area during one or several growing seasons, especially in the tropical regions of South America, Africa, and parts of Asia, where people need additional opportunities to produce food. Thus, the sustainable intensification of crop and livestock production in ICL systems managed by small farmers is crucial to mitigate human suffering, which is necessary for social and economic changes.

Acknowledgements The authors would like to thank the São Paulo Research Foundation (FAPESP, Grant \#2003/09914-3) and the Coordination for the Improvement of Higher Education Personnel (CAPES, PROAP_-Program to Support Graduate) for financial support. In addition, the first and fourth authors would like to thank the National Council for Scientific and Technological Development (CNPq) for an award for excellence in research.

\section{References}

Agrolink (2018) Quotations to farming. https://www.agrolink. com.br. Accessed 25 Oct 2018

Alcarde JC (1992) Corretivos da acidez dos solos: características e interpretações. São Paulo, ANDA. (Boletim Técnico, 6). (In Portuguese)

Alford CM, Krall JM, Miller SD (2003) Intercropping irrigated corn with annual legumes for fall forage in the high plain. Agron J 95(3):520-525. https://doi.org/10.2134/ agronj2003.5200

Allen VG, Baker MT, Segarra E, Brown CP (2007) Integrated irrigated crop-livestock systems in dry climates. Agron J 99(2):346-360. https://doi.org/10.2134/agronj2006.0148

Alves ME, Lavorenti A (2004) Sulfate adsorption and its relationships with properties of representative soils of the São Paulo State, Brazil. Geoderma 118(1-2):89-99. https://doi. org/10.1016/S0016-7061(03)00186-1
Amaral AS, Anghinoni I, Hinrichs R, Bertol I (2004) Movement of lime particles in the profile of na Inceptisol under notillage (In Portuguese, with English abstract). Rev Bras Cienc Solo 28(2):359-367. https://doi.org/10.1590/S010006832004000200014

Ambrosano EJ, Tanaka RT, Mascarenhas HAA, van Raij B, Quaggio JA, Cantarella H (1997) Leguminosas e oleaginosas. In: van Raij B, Cantarella H, Quaggio JA, Furlani AMC (eds) Recomendação de adubação e calagem para o Estado de São Paulo, 2nd ed., Instituto Agronômico, Campinas, Brazil, pp 189-203 (Boletim Técnico 100). (In Portuguese)

AOAC-Association of Official Analytical Chemists (1990) Official methods of analysis, 15 th edn. AOAC, Washington

Barrow NJ (1985) Reactions of anions and cations with variable-charges soils. Adv Agron 38:183-230. https://doi.org/ 10.1007/978-94-009-3667-6_7

Borghi E, Crusciol CAC, Nascente AS, Souza VV, Martins PO, Mateus GP, Costa C (2013) Sorghum grain yield, forage biomass production and revenue as affected by intercropping time. Eur J Agron 51:130-139. https://doi.org/10. 1016/j.eja.2013.08.006

Bossolani JW, Lazarini E, Santos FL, Sanches IR, Meneghette HHA, Parra LF, Souza LGM (2018) Surface reapplication of lime and gypsum on maize cultivated sole and intercropped with Urochloa. Commun Soil Sci Plant Anal 49(15):1855-1868. https://doi.org/10.1080/00103624. 2018.1475565

Braga GJ, Pedreira CGS, Herling VR, Luz PHC (2007) Grazing efficiency on marandu palisadegrass as affected by herbage allowance (In Portuguese, with English abstract). Pesqu Agropecu Bras 42(11):1641-1649. https://doi.org/10. 1590/S0100-204X2007001100017

Briedis C, Sá JCM, Caires EF, Navarro JF, Inagaki TM, Boer A, Ferreira AO, Quadros Neto C, Canalli LB, Santos JB (2012a) Chances in organic matter pools and increases in carbon sequestration in response to surface liming in an oxisol under long-term no-till. Soil Sci Soc Am J 76(1):151-160. https://doi.org/10.2136/sssaj2011.0128

Briedis C, Sá JCM, Caires EF, Navarro JF, Inagaki TM, Boer A, Quadros Neto C, Ferreira AO, Canalli LB, Santos JB (2012b) Soil organic matter pools and carbon-protection mechanisms in aggregate classes influenced by surface liming in a no-till system. Geoderma 170:80-88. https:// doi.org/10.1016/j.geoderma.2011.10.011

Caires EF, Chueiri WA, Madruga EF, Figueiredo A (1998) Changes in soil chemical characteristics by surface application of lime and gypsum and soybean response in notillage system (In Portuguese, with English abstract). Rev Bras Cienc Solo 22:27-34. https://doi.org/10.1590/S010006831998000100004

Caires EF, Fonseca AF, Feldhaus IC, Blum J (2001) Root growth and nutrient uptake by soybean as affected by lime and gypsum, under a no-tillage system (In Portuguese, with English abstract). Rev Bras Cienc Solo 25(4):1029-1040. https://doi.org/10.1590/S0100-06832001000400025

Caires EF, Alleoni LRF, Cambri MA, Barth G (2005) Surface application of lime for crop grain production under a no-till system. Agron J 97(3):791-798. https://doi.org/10.2134/ agronj2004.0207 
Caires EF, Garbuio FJ, Alleoni LRF, Cambri MA (2006) Surface lime application and black oat cover preceding corn and soybean crops under no-till system (In Portuguese, with English abstract). Rev Bras Cienc Solo 30:87-98. https://doi.org/10.1590/S0100-06832006000100010

Caires EF, Garbuio FJ, Churka S, Barth G, Corrêa JCL (2008) Effects of soil acidity amelioration by surface liming on notill corn, soybean, and wheat root growth and yield. Eur J Agron 28:57-64. https://doi.org/10.1016/j.eja.2007.05.002

Caires EF, Garbuio FJ, Churka S, Joris HAW (2011) Use of gypsum for crop grain production under a subtropical notill cropping system. Agron J 103(6):1804-1814. https:// doi.org/10.2134/agronj2011.0192

Cantarella H, van Raij B, Camargo CEO (1997) Cereais. In: van Raij B, Cantarella H, Quaggio JA, Furlani AMC (eds) Recomendação de adubação e calagem para o Estado de São Paulo, 2nd ed., Instituto Agronômico, Campinas, Brazil, pp 43-71 (Boletim Técnico 100). (In Portuguese)

Castro GSA, Crusciol CAC, Calonego JC, Rosolem CA (2015) Management impacts on soil organic matter of tropical soils. Vadose Zone J 14(1):1-8. https://doi.org/10.2136/ vzj2014.07.0093

Colwell WE, Brady NC (1945) The effects of calcium on yield and quality of large-seed type peanuts. J Am Soc Agron 37(9):413-428

CONAB (2017) Custo da produtção agrícola. https://www. conab.gov.br/. Accessed on 25 Oct 2017. (In Portuguese)

Costa CHM, Crusciol CAC (2016) Long-term effects of lime and phosphogypsum application on tropical no-till soybean-oatsorghum rotation and soil chemical properties. Eur J Agron 74:119-132. https://doi.org/10.1016/j.eja.2015.12.001

Costa A, Rosolem CA (2007) Liming in the transition to no-till under a wheat-soybean rotation. Soil Till Res 97(2):207-217. https://doi.org/10.1016/j.still.2007.09.014

Costa KAP, Rosa B, Oliveira IP, Custódio DP, Silva DC (2005) Effect of seasonal climate condition on the dry matter production and bromatological composition of Brachiaria brizantha cv. Marandu (In Portuguese, with English abstract). Cienc Anim Bras 6(3):187-193

Costa NR, Andreotti M, Crusciol CAC, Pariz CM, Lopes KSM, Yokobatake KLA, Ferreira JP, Lima CGR, Souza DM (2016) Effect of intercropped tropical perennial grasses on the production of sorghum-based silage. Agron $\mathbf{J}$ 108(6):2379-2390. https://doi.org/10.2134/agronj2016.07. 0385

Crusciol CAC, Mateus GP, Nascente AS, Martins PO, Borghi E, Pariz CM (2012) An innovative crop-forage intercrop system: early cycle soybean cultivars and palisadegrass. Agron J 104(4):1085-1095. https://doi.org/10.2134/ agronj2012.0002

Crusciol CAC, Nascente AS, Mateus GP, Borghi E, Leles EP, Santos NCB (2013) Effect of intercropping on yields of corn with different relative maturities and palisadegrass. Agron J 105(3):599-606. https://doi.org/10.2134/agronj2012.0426

Crusciol CAC, Nascente AS, Mateus GP, Pariz CM, Martins PO, Borghi E (2014) Intercropping soybean and palisadegrass for enhanced land use efficiency and revenue in a no till system. Eur J Agron 58:53-62. https://doi.org/10.1016/ j.eja.2014.05.001

Crusciol CAC, Nascente AS, Borghi E, Soratto RP, Martins PO (2015) Improving soil fertility and crop yield in a tropical region with palisadegrass cover crops. Agron J 107(6):2271-2280. https://doi.org/10.2134/agronj14.0603

Crusciol CAC, Marques RR, Carmeis Filho ACA, Soratto RP, Costa CHM, Ferrari Neto J, Castro GSA, Pariz CM, Castilhos AM (2016a) Annual crop rotation of tropical pastures with no-till soil as affected by lime surface application. Eur J Agron 80:88-104. https://doi.org/10. 1016/j.eja.2016.07.002

Crusciol CAC, Artigiani ACCA, Arf O, Carmeis Filho ACA, Soratto RP, Nascente AS, Alvarez RCF (2016b) Soil fertility, plant nutrition, and grain yield of upland rice affected by surface application of lime, silicate, and phosphogypsum in a tropical no-till system. CATENA 137:87-99. https://doi.org/10.1016/j.catena.2015.09.009

Derpsch R, Friedrich T (2009) Development and current status of no-till adoption in the world. In: Proceedings on CD, 18th triennial conference of the international soil tillage research organization (ISTRO), Izmir, Turkey, June 15-19, 2009

Ernani PR, Ribeiro MFS, Bayer C (2004) Chemical modifications caused by liming below the limed layer in a predominantly variable charge acid soil. Commun Soil Sci Plan 35(5-6):889-901. https://doi.org/10.1081/CSS-120030365

Fox DG, Tedeschi LO, Tylutki TP, Russell JB, van Amburgh ME, Chase LE, Pell AN, Overton TR (2004) The Cornell Net Carbohydrate and protein system model for evaluating herd nutrition and nutrient excretion. Anim Feed Sci Technol 112(1-4):29-78. https://doi.org/10.1016/j.anifeedsci.2003. 10.006

Franzluebbers AJ, Stuedemann JA (2014) Crop and cattle production responses to tillage and cover crop management in an integrated crop-livestock system in the southeastern USA. Eur J Agron 57:62-70. https://doi.org/10.1016/j.eja. 2013.05.009

Gatiboni LC, Saggin A, Brunetto G, Horn D, Flores JPC, Rheinheimer DS, Kaminski J (2003) Changes in properties of a sandy soil under no tillage by surface liming (In Portuguese, with English abstract). Cienc Rural 33(2):283-290. https://doi.org/10.1590/S0103-84782003000200016

Gillman GP (1979) A proposed method for the measurement of exchange properties of highly weathered soils. Aust J Soil Res 17(1):129-139. https://doi.org/10.1071/SR9790129

Herrero M, Thornton PK, Notenbaert AM, Wood S, Msangi S, Freeman HA, Bossio D, Dixon J, Peters M, van Steeg J, Lynam J, Rao PP, Macmillan S, Gerard B, McDermott J, Seré C, Rosegrant M (2010) Smart investments in sustainable food production: revisiting mixed crop-livestock systems. Science 327(5967):822-825. https://doi.org/10.1126/ science. 1183725

Ma T, Zuazaga G (1942) Micro-Kjeldahl determination of nitrogen. A new indicator and an improved rapid method. Ind Eng Chem Anal Ed 14(3):280-282. https://doi.org/10. 1021/i560103a035

Malavolta E, Vitti GC, Oliveira AS (1997) Avaliação do estado nutricional das plantas: princípios e aplicações, 2nd edn. POTAFOS, Piracicaba (In Portuguese)

Marsh BH, Grove JH (1992) Surface and subsurface soil acidity: soybean root response to sulfate-bearing spent lime. Soil Sci Soc Am J 56(6):1837-1842. https://doi.org/10.2136/ sssaj1992.03615995005600060031x 
Marsh KB, Tillman RW, Syers JK (1987) Charge relationships of sulfate sorption by soils. Soil Sci Soc Am J 51(2):318-323. https://doi.org/10.2136/sssaj1987. 03615995005100020011x

Martins AP, Anghinoni I, Costa SEVGA, Carlos FS, Nichel GH, Silva RAP, Carvalho PCF (2014a) Amelioration of soil acidity and soybean yield after surface lime reapplication to a long-term no-till integrated crop-livestock system under varying grazing intensities. Soil Till Res 144:141-149. https://doi.org/10.1016/j.still.2014.07.019

Martins AP, Costa SEVGA, Anghinoni I, Kunrath TR, Balerini F, Cecagno D, Carvalho PCF (2014b) Soil acidification and basic cation use efficiency in an integrated no-till croplivestock system under different grazing intensities. Agr Ecosyst Environ 195:18-28. https://doi.org/10.1016/j. agee.2014.05.012

Martins AP, Cecagno D, Borin JBM, Arnuti F, Lochmann SH, Anghinoni I, Bissani CA, Bayer C, Carvalho PCF (2016) Long-, medium- and short-term dynamics of soil acidity in an integrated crop-livestock system under different grazing intensities. Nutr Cycl Agroecosyst 104(1):67-77. https://doi.org/10.1007/s10705-015-9759-5

Mateus GP, Crusciol CAC, Pariz CM, Borghi E, Costa C, Martello JM, Franzluebbers AJ, Castilhos AM (2016) Sidedress nitrogen application rates to sorghum intercropped with tropical perennial grasses. Agron J 108(1):433-447. https://doi.org/10.2134/agronj2015.0236

Miyazawa M, Pavan MA, Calegari A (1993) Effect of plant material on soil acidity (In Portuguese, with English abstract). Rev Bras Cienc Solo 17(3):411-416

Nakagawa J, Rosolem CA (2005) Nutrient concentration in leaves and grains of black oat affected by phosphorus and potassium fertilization (In Portuguese, with English abstract). Bragantia 64(3):441-445. https://doi.org/10. 1590/S0006-87052005000300014

Nora DD, Amado TJC (2013) Improvement in chemical attributes of Oxisol subsoil and crop yields under no-till. Agron J 105(5):1393-1403. https://doi.org/10.2134/agronj2013. 0031

Nora DD, Amado TJC, Nicoloso RS, Gruhn EM (2017a) Modern high-yielding maize, wheat and soybean cultivars in response to gypsum and lime application on no-till oxisol. Rev Bras Cienc Solo 41:e0160504. https://doi.org/ 10.1590/18069657rbcs20160504

Nora DD, Amado TJC, Nicoloso RS, Mazuco ACB, Piccin M (2017b) Mitigation of the gradient of chemical properties in the rooting zone of dystrophic Oxisols by gypsum and lime inputs under a no-till system. Rev Bras Cienc Solo 41:e0150541. https://doi.org/10.1590/18069657rbcs 20150541

Pariz CM, Andreotti M, Bergamaschine AF, Buzetti S, Costa NR, Cavallini MC, Ulian NA, Luiggi FG (2011) Yield, chemical composition and chlorophyll relative content of Tanzania and Mombaça grasses irrigated and fertilized with nitrogen after corn intercropping. Rev Bras Zootec 40(4):728-738. https://doi.org/10.1590/S1516-35982011000400005

Pariz CM, Costa C, Crusciol CAC, Meirelles PRL, Castilhos AM, Andreotti M, Costa NR, Martello JM, Souza DM, Sarto JRW, Franzluebbers AJ (2016) Production and soil responses to intercropping of forage grasses with corn and soybean silage. Agron J 108(6):2541-2553. https://doi.org/ 10.2134/agronj2016.02.0082

Pariz CM, Costa C, Crusciol CAC, Meirelles PRL, Castilhos AM, Andreotti M, Costa NR, Martello JM, Souza DM, Protes VM, Longhini VZ, Franzluebbers AJ (2017a) Production, nutrient cycling and soil compaction to grazing of grass companion cropping with corn and soybean. Nutr Cycl Agroecosyst 108(1):35-54. https://doi.org/10.1007/ s10705-016-9821-y

Pariz CM, Costa C, Crusciol CAC, Castilhos AM, Meirelles PRL, Roça RO, Pinheiro RSB, Kuwahara FA, Martello JM, Cavasano FA, Yasuoka JI, Sarto JRW, Melo VFP, Franzluebbers AJ (2017b) Lamb production responses to grass grazing in a companion crop system with corn silage and oversowing of yellow oat in a tropical region. Agric Syst 151:1-11. https://doi.org/10.1016/j.agsy.2016.11.004

Quaggio JA, van Raij B (1997) Correção da acidez do solo. In: van Raij B, Cantarella H, Quaggio JA, Furlani AMC (eds) Recomendação de adubação e calagem para o Estado de São Paulo, 2nd ed., Instituto Agronômico, Campinas, Brazil, pp 14-19 (Boletim Técnico 100). (In Portuguese)

Quaggio JA, Dechen AR, van Raij B (1982) Effects of lime and gypsum application on peanut yield and base leaching in the soil (In Portuguese, with English abstract). Rev Bras Cienc Solo 6(3):189-194

Rampim L, Lana MC, Frandoloso JF, Fontaniva S (2011) Chemical attributes of a soil and response of wheat and soybean to gypsum in no-tillage system (In Portuguese, with English abstract). Rev Bras Cienc Solo 35(5):1687-1698. https://doi.org/10.1590/S010006832011000500023

Rampim L, Lana MC, Frandoloso JF (2013) Available phosphorus and sulphur, exchangeable aluminum and remaining phosphorus in rhodic eutrudox submitted to gypsum cultivated with wheat and soybean (In Portuguese, with English abstract). Semin Cienc Agrar 34(4):1623-1638. https://doi. org/10.5433/1679-0359.2013v34n4p1623

Rosolem CA, Foloni JSS, Oliveira RH (2003) Nitrogen dynamics in soil as affected by liming and nitrogen fertilization, with straw on the soil surface (In Portuguese, with English abstract). Pesqu Agropecu Bras 38(2):301-309. https://doi.org/10.1590/S0100-204X2003000200018

Sato S, Comerford NB (2005) Influence of soil pH on inorganic phosphorus sorption and desorption in a humid Brazilian Ultisol. Rev Bras Cienc Solo 29(5):685-694. https://doi. org/10.1590/S0100-06832005000500004

Silva IR, Mendonça ES (2007) Matéria orgânica do solo. In: Novais RF, Alvarez VVH, Barros NF, Fontes RLF, Cantarutti RB, Neves JCL (eds) Fertilidade do solo. Sociedade Brasileira de Ciência do Solo, Viçosa, pp 275-374 (In Portuguese)

Soratto RP, Crusciol CAC (2008a) Chemical soil attributes as affected by lime and phosphogypsum surface application in a recently established no-tillage system (In Portuguese, with English abstract). Rev Bras Cienc Solo 32(2):675-688. https://doi.org/10.1590/S0100-06832008 000200022

Soratto RP, Crusciol CAC (2008b) Dolomite and phosphogypsum surface application effects on annual crops nutrition and yield. Agron J 100:261-270. https://doi.org/10.2134/ agronj2007.0120 
Soratto RP, Crusciol CAC (2008c) Nutrition and grain yield of black oat as affected by surface application of lime and phosphogypsum at the establishment of no-tillage system (In Portuguese, with English abstract). Rev Bras Cienc Solo 32(2):715-725. https://doi.org/10.1590/S010006832008000200026

Sumner ME (1990) Gypsum as an ameliorant for the subsoil acidity syndrome, University of Georgia, Bartow, USA. (Publication no 01-024-090). http://www.soilsolutions.net/ wp-content/uploads/2015/02/Effect-of-Gypsum-onDecreasing-Subsoil-Acidity.pdf. Acessed 22 Mar 2018

Sumner ME, Shahandeh H, Bouton J, Hammel J (1986) Amelioration of an acid soil profile through deep liming and surface application of gypsum. Soil Sci Soc Am J 50(5):1254-1258. https://doi.org/10.2136/sssaj1986. 03615995005000050034x

Tiritan CS, Büll LT, Crusciol CAC, Carmeis Filho ACA, Fernandes DM, Nascente AS (2016) Tillage system and lime application in a tropical region: soil chemical fertility and corn yield in succession to degraded pastures. Soil Till Res 155:437-447. https://doi.org/10.1016/j.still.2015.06.012

Unicamp (2016) Centro de Pesquisas Meteorológicas e Climáticas Aplicadas a Agricultura. Clima dos Municípios Paulistas, Botucatu. Cepagri Meteorologia-UNICAMP. http://www.cpa.unicamp.br/outras-informacoes/clima_ muni_086.html\#. Accessed 06 Nov 2016. (In Portuguese)

United States Department of Agriculture (USDA) (1999) Soil taxonomy: a basic system of soil classification for making and interpreting soil surveys, 2nd edn. Agriculture Handbook. USDA, NRCS, Washington, D.C. https://www.nrcs.
usda.gov/Internet/FSE_DOCUMENTS/nrcs142p2_ 051232.pdf. Accessed 10 June 2018

van Raij B, Andrade JC, Cantarella H, Quaggio JA (2001) Análise química para avaliação da fertilidade de solos tropicais. IAC, Campinas (In Portuguese)

van Soest PJ (1994) Nutritional ecology of the ruminant, 2nd edn. Cornell University Press, Ithaca

Vitti GC (1988) Avaliação e interpretação do enxofre no solo e na planta. FUNEP, Jaboticabal (In Portuguese)

Viviani CA, Marchetti ME, Vitorino ACT, Novelino JO, Gonçalves MC (2010) Phosphorus availability in two clayey oxisols and its accumulation in soybean as a function of the increase in $\mathrm{pH}$ (In Portuguese, with English abstract). Cienc Agrotecnol 34(1):61-67. https://doi.org/10.1590/ S1413-70542010000100007

Walkley A, Black IA (1934) An examination of the Degtjareff method for determining soil organic matter, and a proposed modification of the chromic acid titration method. Soil Sci 37(1):29-38. https://doi.org/10.1097/00010694193401000-00003

Wirsenius S, Azar C, Berndes G (2010) How much land is needed for global food production under scenarios of dietary changes and livestock productivity increases in 2030? Agric Syst 103(9):621-638. https://doi.org/10.1016/ j.agsy.2010.07.005

Publisher's Note Springer Nature remains neutral with regard to jurisdictional claims in published maps and institutional affiliations. 